\title{
A broken system: the persistent patterns of reversals of death sentences in the United States*
}

\author{
Andrew Gelman ${ }^{\dagger} \quad$ James S. Liebman $^{\ddagger} \quad$ Valerie West $^{\S}$ Alexander Kiss ${ }^{\nwarrow}$
}

September 26, 2003

${ }^{*} 14000$ words (not counting reference list, tables, and figures)

We thank Yves Chretien, Garth Davies, Jeffrey Fagan, Alexander Kiss, and Jonathan Lloyd for preparation and analysis of the data and the U.S. National Science Foundation and National Institute of Justice for financial support through grants SES9987748 and NIJ-2000-IJ-CX-0035. Points of view in this article are those of the authors and do not necessarily represent the official position or policies of the National Science Foundation or the U.S. Department of Justice.

${ }^{\dagger}$ Professor, Department of Statistics and Department of Political Science, Columbia University, New York, gelman@stat.columbia.edu. www.stat.columbia.edu/ gelman/

‡Simon H. Rifkind Professor, Columbia Law School, New York

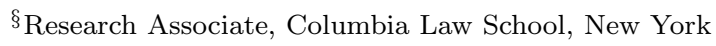

IPh.D. student, Department of Biostatistics, Columbia University, New York 


\title{
A broken system: the persistent patterns of reversals of death sentences in the United States
}

September 26, 2003

\begin{abstract}
We collected data on the appeals process for all death sentences in U.S. states between 1973 and 1995. The reversal rate was high, with an estimated chance of at least $2 / 3$ that any death sentence would be overturned by a state or federal appeals court. Multilevel regression models fit to the data by state and year indicate that high reversal rates are strongly associated with higher death-sentencing rates and lower rates of apprehending and imprisoning violent offenders. In light of our empirical findings, we discuss potential remedies including "streamlining" the appeals process and restricting the death penalty to the "worst of the worst" offenders.
\end{abstract}

\section{The modern death penalty in the United States}

After being temporarily invalidated by the Supreme Court in 1972, the death penalty was reinstated in the United States in a few states in 1973 and gradually spread to most of the rest of the country by the 1990 s. $^{1}$ Figure 1 shows the number of states with valid death penalty statutes; the number of death sentences, executions, and executions per death row population each year since 1973; and the average length of time between sentence and the executions in each of those years. The number of executions rose during most of the 1990s but has never exceeded $3 \%$ of the people under sentence of death in that year (Liebman et al., 2000). Only 5\% of the death sentences imposed during the 23-year period from 1973 to 1995 were carried out in that period, and average time to execution has risen to about 12 years (U.S. Department of Justice, 2001).

\footnotetext{
${ }^{1}$ See Banner (2002), Bowers (1984), Epstein and Kobylka (1992), Paternoster (1991), and Weisberg (1983). On the costs of the death penalty generally, see Baiker (2001) and Constanzo (1997). Summaries of current controversies appear in Acker et al. (1998), Bedau (1997), Garvey (2002), Haas and Inciardi (1998), Hood (1998), Lifton and Mitchell (2000), Sarat (2001), and Zimring (2002).
} 


\section{Figure 1 about here}

In this paper, we analyze the results of all court decisions that reviewed the 6000 U.S. capital verdicts imposed between 1973 and 1995, with the goal of answering three questions posed by Figure 1 that are at the center of the current death penalty debate in the United States.

- What happens to capital verdicts between sentencing and execution? (Greenberg, 1982, Spurr, 2002)

- Why are so few death sentences ultimately carried out? (Aarons, 1998, Amsterdam, 1999, Billionis, 2000)

- Are there changes in death-sentencing policies and practices that can improve the reliability and efficiency of the nation's capital system? (Diamond and Levi, 1996, Garvey, 2002, McCord, 2001, Coleman, 1998, Symposium, 2001, Symposium, 2002)

Answers to these questions may help evaluate the contradictory criticisms of the capital system that define the modern death penalty debate in the United States. In explaining his January 2003 decisions to release three death row inmates because they were innocent and to commute the death sentences of the remaining 164 inmates on the state's death row to life imprisonment without possibility of parole, Illinois Governor George Ryan stated that "[o]ur capital system is haunted by the demon of error, error in determining guilt, and error in determining who among the guilty deserves to die." Believing that the state legislature had failed to exorcise the demon of error, Ryan concluded that the "system is broken." (For related criticisms, see Bienen, 1998, Clark et al., 2000-2001, Black, 1981, Gross, 1996, Huff, 2001, Radelet and Bedau, 1992, Report of the Illinois Governor's Commission, 2002, Steiker and Steiker, 1995, and Symposium, 1998.) Prosecutors countered strongly that the problem with the death penalty is not error but nullification of the popular will to carry it out, through irresponsible reversals of death verdicts by judges who oppose the death penalty and by Ryan himself. (See Blecker, 2002, Kozinski and Gallagher, 1995, Latzer and Cauthen, 2000, Markman and Cassell, 1988, and Williams, 2002.) In order to help resolve this debate, we study the reasons and patterns of death penalty reversals throughout the country over two decades. 


\section{The rate at which death verdicts are reversed}

To understand in detail what happens after state death verdicts are imposed, we collected data on all 5826 such verdicts in the United States from 1973 to 1995 in the 34 states that had active and legally valid death penalty laws during part or all of this period. We did not analyze death verdicts imposed under facially invalid capital statutes but only those imposed between 1973 and 1995 under "guided discretion" statutes of the type the Supreme Court approved in its mid-1970s rulings.

Figure 2 shows the big picture: in the states and years with the death penalty in that period, there were over 300,000 homicides and slightly over 100,000 murder convictions, of which fewer than 6000 resulted in death sentences. Of these death verdicts, $40 \%$ were reversed by state or federal courts as of $1995,6 \%$ had been fully upheld by state and federal courts on a first round of state and federal appeals and post-conviction review, $54 \%$ were still in the appeals process, and only $5 \%$ had been carried out. Of the $46 \%$ of all death verdicts that were fully reviewed at all review stages during the period, $87 \%$ were reversed by state or federal courts.

\section{Figure 2 about here}

The death verdicts in our study can be appealed at three stages of court review:

1. The first stage of review is based on the trial record and is performed by the highest state appellate court with responsibility over criminal cases (in some states after an intermediate appellate court has also reviewed the verdict).

2. Death verdicts approved at the first appeal stage are then reviewed by one or more state courts (usually, the original state trial court and one state appellate court) in a "state post-conviction review" procedure. This procedure focuses on claimed legal errors that were not visible in the original trial record (for example, the defense lawyer's failure to investigate the case, or the withholding of exculpatory evidence by police or prosecutors).

3. Death verdicts approved at the second review are then reviewed by federal trial and appellate courts in a "habeas corpus" procedure that affords review by life-tenured federal judges of all the claimed federal legal errors considered by the (mainly elected) state judges in the first two review stages. 
The United States Supreme Court may agree to hear a small number of claimed federal legal errors following any one of the three review stages, but it rarely exercises that power. Death verdicts that are reversed at one of the three review stages are not reviewed at subsequent stages and instead are returned to the original state trial court for a new trial (in most cases) or for dismissal of the charges. (See Crump and Jacobs, 2000, and Dow and Dow, 2002, for overviews of the review process.)

Figure 3 shows the data for each stage of appeal. Of the cases that as of 1995 were finally reviewed at the direct appeal stage, $1852 /(1852+2694)=41 \%$ were overturned at the state direct appeal. Of the cases that passed this first review, at least 257/2694 $=10 \%$ were reversed by the state post-conviction review. Finally, the Federal habeas review overturned $240 /(240+358)=40 \%$ of the cases that were upheld at both stages of state court review and that were finally reviewed at the third, federal habeas stage of review.

\section{Figure 3 about here}

In most situations involving the production of goods or the provision of services, successive inspections for defects are expected to culminate with a final review at which only a very small number of errors are found. It is worrisome that, even after two stages of state review, the federal courts found reason to reverse $40 \%$ of the remaining capital verdicts (Liebman, 2002).

The number of the 5826 death verdicts that were actually reversed cannot be determined from these data because over half of the cases were still under review as of 1995. Some of them are still under review today. (The average time from sentencing to decision at the third review stage is about 10-12 years, both for cases that are ultimately reversed and those that are affirmed at that stage.) The total error rate can be estimated by combining the conditional probabilities from each of the stages of review:

$$
\begin{aligned}
\operatorname{Pr}(\text { reversed })= & \operatorname{Pr}(\text { reversed at stage } 1)+ \\
& +\operatorname{Pr}(\text { upheld at stage } 1) \times \operatorname{Pr}(\text { reversed at stage } 2 \mid \text { upheld at stage } 1)+ \\
& +\operatorname{Pr}(\text { upheld at stages } 1 \text { and } 2) \times \operatorname{Pr}(\text { reversed at stage } 3 \mid \text { upheld at stages } 1 \text { and } 2) \\
= & 0.41+0.10 \times 0.59+0.40 \times 0.53=0.68,
\end{aligned}
$$

or $68 \%^{2}$. The error rate has remained high during the entire period of the study and is also persistent across

\footnotetext{
${ }^{2}$ This error rate is conservative for three reasons: The estimate of $10 \%$ of reversals at the second stage puts all the unreversed
} 
states. Figure 4 shows the consistently high reversal rates in almost all the death-penalty states.

\section{Figure 4 about here}

\section{Reasons for reversing death sentences}

Not all legal errors found by reviewing courts result in reversals. In most cases, reversal is permitted only if a death row inmate can show (1) that a legal error committed in his or her case was "prejudicial" because there is a "reasonable probability that, but for the error, the outcome would have been different"; (2) that the error affected the verdict in some other identifiable way (that is, was not "harmless"); or (3) that the error (for example, bias against the defendant by the judge who presided at the trial) was "inherently prejudicial" (Carter, 1993, Kirchmeier, 1996, Liebman, 2000, McCord, 1999). We counted only error that actually resulted in reversal by the highest court with authority to review the verdict at the relevant stage of review. If a lower or intermediate court reversed a verdict, we did not count that reversal unless the highest court with power to review the verdict at that stage of review approved the lower court's reversal; if the highest court reinstated the verdict, we treated the verdict as having been upheld. As one means of assessing the seriousness of these reversals, we examined the types of errors that led courts to reverse.

\section{State post-conviction and federal habeas reviews}

We began by examining the reasons for all 497 reversals at the second (state post-conviction) and third (federal habeas corpus courts) review stages. These reversals were about evenly split between state and federal courts. We chose to begin with these review stages because they occur only after the highest court in the state has upheld the verdict at the first review stage and for that reason are sometimes criticized as unnecessarily repetitive and as a source of reversals based on "technicalities" (Latzer and Cauthen, 2000, Hoffmann, 2000, 2001; but see West et al., 2001). We found that most of the reversals at these two review stages occurred where the correct outcome of the trial was in doubt; the reversing courts found that, if it had

cases in the "upheld" category, including many cases that were not reversed or upheld but were still under court review as of 1995; see Figure 3. We did not count reversals occurring at fourth and fifth stages of court review, because those stages are not routine in all capital cases. We did not count decisions by governors to commute death sentences which (as in Illinois) are sometimes based on findings of error, because reasons often are not given for grants of clemency. 
not been for the error, there was a "reasonable probability" that the outcome would have been different. If the error affected the jury's verdict that the defendant was guilty of aggravated capital murder, the different outcome would have been a verdict that the defendant was not guilty of that offense. If the error affected the sentencing verdict but not the verdict that the defendant committed capitally aggravated murder, the different outcome would have been a prison term instead of a death sentence. (Even after guilt has been established, a death sentence is not automatically applied. Instead, the sentencer must evaluate additional evidence and decide whether to impose death or a prison sentence; see Crocker, 1997.) Approximately half of the reversals overturned the determination that the defendant was guilty of aggravated capital murder. The other half affected the capital sentence only.

About $80 \%$ of the state court reversals at the second stage of review, and just under $75 \%$ of the federal court reversals at the third stage of review, were because of egregiously incompetent lawyering, prosecutorial misconduct or suppression of evidence, misinstruction of jurors, or biased judges or jurors. All four of these kinds of error require proof of a "reasonable probability" that the outcome would have been different if the error had not occurred, except for decision maker bias, which is "inherently prejudicial." Incompetent representation by defense lawyers accounted for about one-third of these reversals; misconduct by police and prosecutors and mis-instruction of jurors by judges each accounted for about $20 \%$ of the reversals; decision maker bias accounted for about $3 \%$ of the reversals. The remaining reversals were for a variety of other violations, including forced confessions, the rejection of potential jurors because of their ethnicity, and denial of funds needed for a full defense by indigent defendants.

\section{State direct appeals}

We next reviewed the reasons for reversal given by state high courts for a random sample of 830 of the 1852 reversals at the first stage of court review. $42 \%$ percent of these reversals overturned the verdict that the defendant was guilty of murder; $17 \%$ overturned the determination that defendants guilty of murder were also guilty of capitally aggravated murder. The remaining $41 \%$ of the reversals affected the sentencing determination. In multiple-reversal cases, we weighted each reversible error as 1/(\# of reversible errors found in the case).

The largest single basis for reversal at the direct appeal stage was faulty determination that a circumstance 
the state statute defines as making the murder into a capitally aggravated murder was present in the case. This error occurred in $20 \%$ of the cases sampled and accounts for $17 \%$ of the reversals when the weighting procedure described above is used in cases with multiple errors leading to reversal. Denial of the defendant's right to cross-examine witnesses against him, intentional exclusion of African-Americans from the jury, admission of unreliable evidence, prosecutorial misconduct, and instructions relieving the state of the burden of proving the defendant's guilt beyond a reasonable doubt each accounted for $8-10 \%$ of the reversals of verdicts of guilt. Other bases include incompetent defense representation, judicial bias, coerced confessions, and the absence of sufficient evidence to permit a reasonable juror to conclude that the defendant was guilty.

The basis for overturning a conviction that is typically identified as "frivolous" or a "technicality" is the exclusion of evidence taken from the defendant following a search or arrest conducted without appropriate warrant or "probable cause." This was the basis for reversal in only one of our sample of 829 cases and accounted for less than one-third of one percent of the guilt-stage reversals.

\section{Retrial outcomes following reversals}

To check further whether reversals made a difference, we examined the 257 state post-conviction court reversals to see what happened at retrials when the errors were cured. Retrial outcomes are not published and must be identified by contacting participants in each case. Reversal information for the second stage also has to be collected in this way - unlike the other two stages, where reversal information is published - so we manually collected information on retrial outcomes for the second stage at the same time as we manually collected reversal information for that stage. Sending the case back to cure errors found at the second review stage changed the outcome $82 \%$ of the time, including $9 \%$ of the cases where death-row inmates were found not guilty on retrial. Only $18 \%$ of the retrials resulted in a new death verdict.

We do not know whether the patterns of retrial outcomes at the first and third stages of review are the same as the pattern at the second stage of review. We do not believe those patterns differ substantially, however, because (1) the state high court judges who determine whether errors occurred and whether they are serious enough to require reversal at the first review stages are the same judges who perform the same task at the second review stage (which we studied in this regard); (2) virtually the same types of violations lead to reversals in about the same proportions at the third review stage as at the second stage of review 
that we studied; and (3) available data on retrial outcomes from separate, state-specific studies of Arizona and Tennessee capital reversals (Shiffman, 2001, Stookey, 2003) reveal that retrial outcomes following firstand third-stage reversals are similar to those following second-stage reversals (in both states, non-capital outcomes occurred over $70 \%$ of the time following reversals at the first and third review phases, but were slightly less likely than non-capital outcomes following second-stage reversals).

\section{Absence of evidence of ideological motivation for most reversals}

There is a concern that verdicts may be overturned by appellate judges simply because they are opposed to the death penalty in all cases (Latzer and Cauthen, 2000, Hoffmann, 2001). If so, we obviously should not interpret these rulings as evidence for weaknesses in individual death verdicts. The only example of this possibly occurring that is identified in the literature is the California Supreme Court between 1979 and 1986, when Rose Bird was Chief Justice (Kamin, 2000, Traut and Emmert, 1998, Uelmen, 1989). As revealed by our data on direct appeal reversals in capital cases, the Bird Court reversed 83\% (55/66) of the death verdicts it reviewed before being voted out of office for this and other reasons. The replacement California Supreme Court (under the leadership of Chief Justice Malcolm Lucas) exhibited the opposite pattern, affirming $85 \%$ (174/205) of the death verdicts it reviewed between 1987 and 1995 (see generally Shatz and Rivkind, 1997). Aside from these anomalous California examples, there is no evidence that state or federal judges routinely use only simplistic ideological criteria, entirely unrelated to the circumstances of the case, to review death verdicts. Because we count all death verdicts in the nation that were fully reviewed by the courts during the study period, the inclusion of the California cases tends to deflate the overall error rate we report because the Lucas court, which almost always approved death verdicts, reviewed three times more verdicts than the Bird court, which almost always reversed death verdicts.

More broadly, there is no evidence that judges are systematically disposed to ignore or frustrate the public will on the death penalty. About $90 \%$ of the reversals in our study were by elected state judges - ones who needed the support of a majority of the voters in order to take or remain in office (Bright and Kennan, 1995). Most of the remaining reversals were by federal judges appointed by Republican presidents with strong law-and-order agendas. As have all other academic studies addressing the issue, our study indicates that appellate judges reviewing capital verdicts face especially intense pressure to conform their votes in 
these cases to the views of their constituents - views that since the early 1970s have run heavily in favor of imposing and affirming death verdicts (e.g., Brace and Hall, 1993, Hall, 1992, 1997, and Songer and Tabrizi, 1999). Considering this strong and consistent finding, a careful empirical analysis of the short Bird Court interlude in California concluded that it was a singular anomaly, in which ideological intensity on the part of two or three judges trumped the far more typical tendency of elected appellate judges across the nation to subordinate their ideological views as needed to improve their chances for reelection (Traut and Emmert, 1998). The main importance of the Bird affair is thus as an object lesson for elected judges in California and elsewhere against ideological purism running against the death penalty. There is some evidence, however, that the Bird example has encouraged ideological purism by appellate judges who strongly favor the death penalty (Bright and Kennan, 1995, Culver, 1999, Kamin, 2000, Uelmen, 1989).

The high rates of reversal by both state and federal appellate courts indicate a systematic problem with the way the death penalty is applied in the states. Can anything be done to reduce the error rate? After examining the available literature on this and related questions and discussing our data and methods, we address the question by examining factors that explain the variation in death penalty reversal rates among states.

\section{The existing empirical literature on capital verdicts and appel- late court reversals}

Many studies have been performed examining factors predictive both of decisions to use the death penalty and of rulings by appellate judges and courts. Among the latter studies are a small number addressing the question considered here: what factors influence the decisions of appellate judges and courts to approve or overturn death penalty verdicts? Briefly discussing both sets of studies helps us explain the design, operation, and interpretation of our study and identifies questions left open by the existing research that our study helps to answer. ${ }^{3}$

\footnotetext{
${ }^{3}$ Less relevant here is the large array of (as a whole, inconclusive) studies of the deterrence effect of the death penalty. For a recent survey of this literature, see Cottrol (2000).
} 


\section{Factors predictive of the use of the death penalty}

We are mainly interested in appellate court decisions approving or reversing death verdicts, not trial court decisions imposing such verdicts in the first place. Nevertheless, the vast literature studying decisions to use the death penalty is relevant to our study of decisions to reverse death verdicts because both types of decisions have the same essential result. Both make individuals eligible or ineligible to be executed. Our results demonstrate another important connection between the two kinds of decisions: jurisdictions that use the death penalty more often per homicide have substantially higher rates of capital error than jurisdictions that use the death penalty less frequently.

Most studies of factors influencing the death penalty's imposition examine case-specific factors that potentially affect the probability that a death sentence will be imposed. These studies reveal that the probability of a death sentence increases when there is more salient evidence that the defendant has a prior record of antisocial behavior or revealing aggravating aspects of the offense (Baldus et al., 1990). In addition, jurors and judges who hold conservative ideological and religious attitudes, are white, and are male, are more disposed to impose the death penalty than other jurors and judges (Tyler and Weber, 1982, Songer and Tabrizi, 1999, Vidmar and Ellsworth, 1974).

Studies also suggest the influence of particular trial procedures. The practice of questioning prospective jurors about their views on the death penalty, and of excluding candidates for jury service who oppose the penalty, appears to increase the probability that the jurors who are selected will be persuaded beyond a reasonable doubt by the evidence of the defendant's guilt and will convict him of capital murder (Cowan et al., 1984, Kadane, 1983, Fitzgerald and Ellsworth, 1984). This effect arises even before the jurors reach the separate question of sentence. Being subjected to death qualification questioning before trial also increases the probability that jurors who support the death penalty and are seated on the jury will impose that sentence after finding the defendant guilty and after hearing all of the aggravating and extenuating evidence on the issue of sentence (Haney, 1984).

Whether capital sentencing is by jurors alone, judges alone, or jurors whose decisions may be overridden by judges also seems to affect the probability of a death sentence: judges are more likely than jurors to impose the penalty (Burnside, 1999, Kalven, and Zeisel, 1966, Radelet and Mello, 1992). Increased compensation 
for capital defense lawyers has been correlated with declining death-sentencing rates in Indiana (Lefstein, 1996). And attitude surveys suggest that jurors who are clearly instructed on the binding legal rules that govern capital sentencing proceedings are less likely to impose capital verdicts than jurors who are not given clear instructions on these rules (Bowers and Steiner 1999, Eisenberg et al., 1996, Eisenberg and Wells 1993, Garvey et al., 2000, Hoffmann, 1995). Proximity to upcoming elections for trial judges and governors appears to increase the probability that the judges will impose a death verdict, and that the governors thereafter will issue death warrants (which affect the speed with which death verdicts are carried out) or will decline to commute death sentences to a lesser penalty (Kubik and Moran, 2003, Liebman et al., 2002, Pridemore, 2000).

Personal characteristics of the defendant and especially the victim also affect the probability of a death sentence. A large and generally consistent set of multivariate analyses concludes that the victim's ethnicity (white), sex (female), and status (high standing in the community) are associated with a higher probability that prosecutors will ask for, and that jurors will impose, a death sentence (Baldus et al., 1998, Blume et al., 2002, Bowers et al, 2001, Gross and Mauro, 1989, Paternoster, 2003). The corresponding characteristics of the defendant appear to have less of an effect.

Building on case-level research revealing geographic influences on decisions to impose the death penalty (influences often correlated with racial predictors; see Cohen, 1996, Cohen and Nisbett, 1994, Paternoster, 2003), a number of studies consider social and political forces operating at the jurisdictional level that may account for cross-jurisdictional variance in death-sentencing rates Here again, unsurprising conclusions - that localities characterized by conservative political values, evangelical Christian religious beliefs, and Republican party affiliation tend to have higher death-sentencing rates than other localities - are accompanied by more disturbing findings that economic inequality, higher rates of white homicide victimization, and larger AfricanAmerican populations also predict higher death-sentencing rates (even though African-Americans individuals, when permitted to serve on juries, tend to impose the death penalty less frequently than white jurors; see Eisenberg et al., 2001, Jacobs and Carmichael, 2002, Mitchell and Sidanius, 1995, Nice, 1992, Zimring, 19901991; see Harries and Cheatwood, 1997). Similar racial and economic factors influence state-level variation in rates of execution and in levels of death penalty intensity, measured using a composite of the size of a 
state's death row population and its death-sentencing and execution rates (Langbein, 1999, Lofquist, 2002).

One important theoretical explanation for many of these findings is that the death penalty's use is proportionate to the level of threat to personal safety and security experienced by politically powerful constituencies. Ethnicity comes into play for two reasons. First, ethnicity is associated with political power. Threats to the safety and security of the white community tend to be taken more seriously by law enforcement officials than threats to minority communities (Cole, 1999, Kennedy, 1997). Second, partially through the unfortunate operation of racial stereotypes, citizens and officials tend to use the ethnicity of suspects (particularly if the suspects are African American) and the size of nearby minority populations (especially African-American populations) as proxies for the threat of violent crime posed by particular individuals and present in particular social environments (Bobo and Hutchings, 1996, Garland, 2002, Hurwitz and Pelfey, 1997, Sunnafrank and Fontes, 1983, Taylor, 1998).

\section{Factors predictive of appellate reversals}

As one would expect, the outcomes of judicial cases are influenced, at least in part, by the factors that legal theory has traditionally identified as the legitimate raw material of judicial decision making: fact patterns, legal arguments, and court and fact finding procedures (Faust et al., 1991, Flango and Mckenna, 1995, Songer and Lindquist, 1996). The quality and status of a party's lawyer also appears to affect appellate outcomes, although surprisingly a party's representation by an interest group, such as the NAACP Legal Defense Fund, rather than by a private lawyer, does not appear to influence outcomes of appeals in capital and other cases (Epstein and Rowland 1991, Traub, 1998). Numerous case-level studies have also attempted—with mixed results (Sisk et al., 1998) - to predict the outcomes of judicial decisions based on extra-legal factors that the legal system typically considers illegitimate. Factors that may have this kind of effect under some circumstances include judges' personal traits including their racial, social and economic backgrounds, prior experience as a prosecutor, and levels of education and professional experience (Aliotta, 1988, Ashenfelter et al., 1995, Sisk et al., 1998, Tate and Handberg, 1991); religious beliefs (Songer and Tabrizi, 1999), political party affiliations (Lloyd, 1995, Pinello, 1999); attitudes and ideological orientation (Cross, 1997, Emmert and Traut, 1994, Epstein and Mershon, 1996, Johnson, 1987, Lloyd, 1995, Segal et al., 1995, Segal and Spaeth, 1993, Smith and Hensly, 1993); and the sources of campaign contributions to judges (Ware, 2002). More 
consistently predictive of judicial outcomes are public opinion and the preferences of voters in the relevant jurisdictions (Eskridge et al., 2003, Mishler and Sheehan, 1993, Swanson and Melone, 1995).

Institutional factors affecting case-level and jurisdictional variation in appellate decisions include levels of public expenditures on courts, judicial workloads, and trends in the decisions of superior courts. For example, elected state appellate judges became less willing to reverse capital sentences in the 1980s and 1990s as the membership and decisions of the United States Supreme Court become more conservative (Brace and Hall, 1993, 1997). Particular attention has been paid to institutional conditions affecting how public opinion is transmitted to, and how powerfully it influences, judges. One important set of studies considers the effect of two alternative methods of selecting judges - elections versus appointment. In simple comparisons that do not distinguish among legal issues being addressed by courts, the use of one judicial selection method as opposed to the other has not consistently predicted outcomes (Flango and Ducat, 1979, Hall, 1992, Pinello, 1995, Slotnick, 1984).

More recent studies have developed an integrated model of judicial decision making, which indicates that judicial decisions are the result of a complex interaction of preferences, rules, and structures and that institutional influences are best understood in conjunction with case characteristics and ideological influences (George and Epstein, 1992, Songer and Haire, 1992). These studies conclude that elected appellate judges do sometimes feel decisive pressure to conform their votes to public preferences, but only when deciding limited types of controversial issues that are highly salient to voters and strongly provoke public debate. Such pressures are further intensified by other institutional conditions - as when these kinds of volatile issues arise during the last two years of a judge's elected term when a reelection campaign is being contemplated or is occurring, and in states where the terms of elected judges are short, there is strong inter-party competition in judicial and other elections, and judicial elections are competitive rather than up-or-down votes on the retention of incumbent judges (Emmert and Traut, 1994, Glick and Pruet, 1986, Hanssen, 1999, Traut and Emmert, 1998).

\section{Factors predictive of appellate reversals in capital cases}

Death penalty appeals have consistently been found to be among the most volatile cases decided by state supreme courts, with the consequence that the pressures on elected appellate judges to conform their votes 
to constituent preferences are higher in death penalty cases than in most or all others (Brace and Hall, 1993, Hall, 1987, 1992). It is "fundamentally the case in death penalty appeals that state supreme court justices have predispositions that are consistent with the states' electoral and ideological environments" (Brace and Hall, 1997). Public preferences on the death penalty also affect the decisions of unelected federal appellate judges in capital cases (Traub, 1998, Eskridge et al. 2003). Constituent preferences ran strongly and increasingly in favor of imposing, affirming, and carrying out death verdicts throughout the period of our study (Tauber, 1998).

Given these conclusions, our findings that state courts overturn $47 \%$ of the death verdicts they review, and that federal judges reverse $40 \%$ of the verdicts that survive state review, are surprising. We are aware of only one study previous to ours that attempts to use cross-state variation to explain high capital reversal rates, that of Blume and Eisenberg (1999). The single predictor on which their focused - whether or not the state selects its judges using partisan elections - had no significant effect on cross-jurisdiction variation in capital error rates. In some, but not all of their analyses, however, they found that death verdicts imposed in states with high rates of death verdicts per murders (what they call high "death-obtaining rates") tend to be reversed more often than verdicts imposed in states that use the death penalty more sparingly. The authors offer no explanation for this partial result.

\section{Data and methods}

\section{Obtaining data on death penalty appeals}

We assembled three data sets, unique to this study, containing the final outcomes between 1973 and 1995 of all state direct appeals of capital verdicts, all state post-conviction review procedures reversing capital verdicts, and all capital federal habeas corpus proceedings - over 5800 decisions in all. For all of the state direct appeal and federal habeas corpus decisions, and for a fraction of the state post-conviction decisions, we identified the relevant decisions using the names of individuals known to have been sentenced to die in the relevant period as search criteria in the Westlaw and Lexis legal search engines. Information maintained in those search engines also enabled us to be certain that the outcomes we collected were final and were not overturned or subject to further review by any higher court. To identify the names of capitally sentenced individuals, we began with the quarterly census of death row inmates maintained by the NAACP Legal Defense Fund from 
1973 to the present. We supplemented that compendium with lists of death row inmates collected by the Death Penalty Information Center in Washington, D.C., and by death penalty resource centers and individual lawyers in most of the states and with keyword searches of legal and newspaper databases. Because many decisions at the state post-conviction stage of review are not accessible through electronic search engines, we identified the relevant decisions in telephone and email conversations with multiple death penalty lawyers in each death-sentencing state, then obtained the unpublished decisions from court files or law offices. All of our information about appellate outcomes in capital cases is from public court records, and all of the data underlying the findings reported here are posted on the website of the Inter-University Consortium of Political and Social Research at the University of Michigan (www.icpsr.umich.edu/).

In addition to the outcome of each appeal, we collected information on the year of the death verdict, the state and county in which it was imposed, and the year of the final decision. For a sample of 830 of the state direct appeal decisions and for all of the state post-conviction and federal habeas corpus reversals we collected information on the reason for reversal when that was the final outcome. For each of the 600 federal habeas corpus cases, we reviewed every published lower state and federal court opinion as well as the final opinion in the case (typically four opinions per case) to collect data on several hundred attributes of the case in nine categories - location, timing, offense, defendant, victim, lawyers, judges, procedures, and legal claims. Data used for the predictors in our regression study of inter-state variation of capital reversal rates were obtained from the United States Census, the FBI Uniform Crime Reports, the Vital Statistics of the United States and other data sets on crime victimization maintained by the National Center for Health Statistics, the Source Book of Criminal Justice Statistics (prison population), State Court Statistics (caseloads), Expenditure and Employment Data for the Criminal Justice System, the Statistical Abstract of the United States (welfare recipients and expenditures), and a data set created by Professor Steven F. Messner and his colleagues at the University of Albany and University of Illinois with county population, crime, and socio-economic data (Messner et al., 1999).

\section{Developing predictors at the state and county level}

In the standard view coming from Congress and the Supreme Court, variation in the outcomes of capital review proceedings is largely a function of the federal circuit court that conducts the final (federal habeas 
corpus) stage of review. As Senator Orrin Hatch expressed the assumption in a congressional debate over legislation to limit habeas corpus review, citing the United States Court of Appeals for the Ninth Circuit in San Francisco as an example, "one of the biggest problems [is] loony judges in the federal courts who will basically grant a habeas corpus petition for any reason at all" (Hatch, 1996; see Gomez v. United States Dist. Ct. 1992). Confirming the conclusion of a recent study of the determinants of time to execution (Spurr, 2002), our results show that this assumption does not hold up under scrutiny. As Figure 5 reveals, the same circuit judges reviewing capital verdicts from different states within their regional jurisdictions reverse capital verdicts at substantially different rates depending upon the verdicts' state of origin. Likewise, when added as variables in our models, federal judicial circuits were not significant predictors. States thus appear to be a more promising jurisdictional unit of analysis.

\section{Figure 5 about here}

What, then, can be learned about the determinants of capital reversals by applying the case-level findings described in the previous section to a study of variance among states in the rate at which their capital verdicts are reversed?

To help us answer this question, we had to develop jurisdiction-level predictors that parallel important determinants previously identified at the case level. Most important and conceptually difficult is a jurisdiction-level analogue to the ethnicity of the victim at the case level - a factor that many death penalty researchers treat as a proxy for the threat felt by members of the white community from homicide and other violent crime. One jurisdiction-level analogue is the proportion of a state's death row inmates who were placed there for killing white victims - or, perhaps, the difference between that proportion and the proportion of all homicides in the state that were committed against white victims. Although we have developed variables of this sort, they have not proved to be predictive (see Liebman et al., 2002). Other jurisdiction-level analogues to the ethnicity of victim that have been proposed are the state's overall homicide rate and the homicide rate among a state's white population (homicides against white victims, divided by the number of white residents); see Langbein (1999). We hypothesize instead that the degree of threat the white community feels from homicide is likely to be best captured by a combination of how many homicides occur in the state and how many of them affect the white as opposed to minority communities. To measure 
this phenomenon, we divide the rate of homicide victimization among a state's white population by the rate of homicide victimization among its African-American population. To anticipate our results briefly, we find that the state's overall homicide rate and the homicide rate among whites are positively correlated with capital error rates but, as hypothesized, that our new measure of the distribution of the homicide threat to the white community is a more powerful predictor than the alternative measures.

We used the proportion of the jurisdiction's population made up of African-Americans as a measure of the effect of ethnicity and of the threat felt by the white population as a result of stereotypical associations between crime and minority populations. Based on case-level findings that so-called black on white crimes pose the largest sense of threat to the white community (Baldus et al., 1990), we hypothesize that our two jurisdiction-level indicators of how much of a homicide threat is perceived by the white community — the size of the black population, and the extent of the state's homicide problem falling on whites - might aggravate each other. To test this hypothesis, we create a third racial variable measuring the interaction of the first two.

Another measure of threat available at the jurisdictional level is the state's efficiency in capturing, prosecuting and punishing serious criminals. We hypothesize that individuals in states with ineffective law enforcement systems feel more threat than individuals in states where a relatively high proportion of serious criminals are caught and incarcerated. To generate a punishment index, we divide the number of serious crimes (FBI index crimes) committed in each state in each year by the number of prisoners incarcerated in the state in that year.

We use four measures of political pressure on judges from particular constituencies and institutional arrangements. To test the influence of public opinion, ideology and political party, we use the party-adjusted ideology score developed in Brace et al. (2000). This is a composite measure of state judges' party affiliations and the ideological disposition of the electorate. To test the influence of members of religious groups shown by other research to influence behavior in capital cases (Eisenberg et al., 2001, Songer and Tabrizi, 1999), we use the proportion of a state's population made up of members of a pooled set of fundamentalist Protestant denominations identified for this purpose by Johnson et al. (1997). We measured the level of political competition in each state based on the relative proportion of each state's electorate composed of registered 
Democrats and Republicans (Stanley and Niemi, 1999). Because nearly all the states in our study subject judges to some sort of elections, we developed an index of political pressure on judges based on differences in election methods that determine the extent of judges' vulnerability to electoral discipline for unpopular decisions: whether judges are elected or appointed, whether elections are partisan or nonpartisan, how long judges' initial term of office lasts (which determines the proximity of decisions to elections), and whether decisions to retain judges after their initial term are based upon contested elections or uncontested (up-ordown) retention votes. All of these variables are positively correlated with error rates. We find that only the last-mentioned factor-how much pressure judicial selection techniques place on state judges to conform to constituents' views on controversial issues - has a consistently significant effect when included in regression analyses with other variables.

We avoid one other methodological limitation of many of the studies of death-sentencing and appellate court behavior that we discuss in the previous section. Although those studies identify statistically significant influences on the relevant behaviors, they often do not report information allowing readers to assess and compare the size of these significant effects. Effect size is particularly important in a context such as this in which there are strong theoretical and empirical reasons to assume that a number of different kinds of conditions (e.g., case, decision maker, jurisdictional, political and institutional characteristics) will affect outcomes, making the crucial question the comparative importance (as well as the interaction) of those predictors. For this reason, we are primarily concerned in the study we report below with the expected effect of each predictor on the probability of reversal of capital verdicts.

\section{Hierarchical logistic regression model}

We fit hierarchical (multilevel) logistic regression models to the probability $p_{s t}$ that a death sentence in state $s$ implemented in year $t$ is ultimately reversed. Specifically, we model $y_{s t}$, the number of ultimately reversed death sentences:

$$
\begin{aligned}
y_{s t} & \sim \text { overdispersed Binomial }\left(n_{s t} p_{s t}\right) \\
\operatorname{logit}\left(p_{s t}\right) & =X_{s t} \beta+\alpha_{s}+\gamma_{t}+\delta t
\end{aligned}
$$


where $n_{s t}$ is the number of death sentences in that state and year, $X$ is a matrix of predictors characterizing the state and year, $\alpha_{s}$ and $\gamma_{t}$ are estimated effects for state and years (after controlling for the regression predictors), and $\delta$ picks up any overall linear time trend. The random effects $\alpha_{s}$ and $\gamma_{t}$ are given normal distributions with means of 0 (which is acceptable because the regression includes a constant term; see, e.g., Gelman et al., 1995) and standard deviations $\sigma_{\alpha}, \sigma_{\gamma}$, which are estimated from data. The model includes overdispersion because the data variance cannot be explained simply by the available predictors and binomial variability. We consider various sets of predictors in $X$ and fit each model using the SAS Glmmix procedure. ${ }^{4}$

${ }^{4} \mathrm{~A}$ potential problem with the model arises because of censoring: many of the cases were still in the middle of the appeals process at the stopping point of our study (the end of 1995), and the eventual disposition $y_{s t}$ of these cases is unknown to our analysis. This difficulty is inevitable in studying an ongoing process, particularly one such as capital review that takes an average of about twelve years to be completed. Under these circumstances, any effort to include recent as well as older cases assures that right censoring will occur because of the long time lag before all of the recent cases complete the process.

We address this issue in three ways. First, we compared our main study, in which censoring occurred because we analyzed reversals as a proportion of all imposed death verdicts - including many verdicts that were not finally reviewed by the end of the study period - to sub-studies in which we analyzed reversal rates at only a single stage of court review and thus could moderate the censoring problem by limiting the cases being studied to those that were fully reviewed at that stage. As we discuss, the results of these single-stage analyses are substantially the same as the results of our main (three-stage) analysis.

Second, we included as predictors a time trend and indicators for the year a verdict was imposed, in part to see if (as one would expect), its effect would change when full right censoring was occurring and when it was not. As predicted, in our main analysis in which censoring occurred, rates of reversal as a proportion of imposed verdicts were lower for verdicts imposed in later years than for verdicts imposed in earlier years. This result is expected, because verdicts that had not been fully reviewed at all review stages as of 1995 had less of a chance (or in some cases, had no chance at all) to be reversed as of 1995 because verdicts that have not been reviewed by one or more courts cannot be reversed (or upheld). One would expect this effect to moderate or to reverse in sub-studies in which reversal rates are calculated as a proportion of verdicts that have been fully reviewed at the court stage being studied. This, indeed, is what occurred. In our main analysis, reversal rates as a proportion of imposed verdicts are about twice as high for the earliest than for the most recent death verdicts, when other predictors are held constant at their averages. But in our sub-study of reversal rates reviewed only at the first (state direct appeal) stage, this effect reverses: reversal rates as a proportion of reviewed verdicts are about eight times lower for the earliest than for the most recent death verdicts, when other predictors are held constant at their averages.

Finally, we conducted a sub-study that removed the effect of time passage of time by aggregating the data in each state over the entire period. The results of this model were consistent with the results of our main state-year analysis. 
We are primarily interested in the coefficients $\beta$ or, more precisely, the expected change in the probability of reversal corresponding to changes in each predictor $X$. The hierarchical parameters $\alpha_{s}$ and $\delta_{t}$ represent variation among states and years that is not explained by our linear predictors. Rather than present tables of coefficient estimates, we discuss the predictors that have large and statistically significant coefficients in our regressions and display their estimated effects graphically.

We fit our main model at the level of states and years, with the binary outcome $y_{s t}=1$ corresponding to reversal at any of the stages. We also analyze the state direct appeal and Federal habeas review separately, fit the model at the county level, and fit a logistic regression to individual case-level data for habeas review. We discuss the results of each analysis in turn.

\section{Results}

\section{State-year analysis of the combined review process}

We fitted the hierarchical logistic regression model with several different combinations of the state-year predictors and obtained similar results. Reversal rates are consistently high in most states and years; however, certain factors are consistently predictive of higher reversal rates. We display summaries of the predictors and regression results in Tables 1 and 2 but we prefer to summarize the results for each of the important predictors graphically, as shown in Figure 6 and discussed in detail here.

\section{Table 1 about here}

Table 2 about here

\section{Figure 6 about here}

Four input variables have the largest expected effect on capital error rates, with the probability that a death verdict is reversed increasing by a factor of about 5 or more across the range of values for each input as represented by the 520 combinations of states and years in our study (holding all other predictors constant at their averages).

First, higher death-sentencing rates (death sentences per 1000 homicides) are associated with higher probability of reversal of any death verdict that is imposed (a result consistent with Blume and Eisenberg, 1999). As Figure 6a shows, when other factors are held constant at their average values, the predicted probability of reversal increases about seven-fold when moving from states and years with the fewest to 
those with the most death sentences imposed per 1000 homicides.

Second, the lower the proportion of its serious criminals a state manages to arrest, convict and incarcerate (as measured by prison population per FBI Index Crimes), the higher is the probability that any death verdict it imposes will be reversed as a result of consequential error. As is shown in Figure 6b, other things equal, the predicted probability of reversal is about seven times higher in states and years with the lowest rates of efficiency in capturing, convicting and imprisoning violent offenders than in the states and years with the highest rates of efficiency. States with more efficient law enforcement systems commit fewer errors in processing capital cases.

Third, in states with a larger number of death verdicts that are stacked up in the courts awaiting appellate review, there is a lower probability that a death verdict will be reversed (see Figure 6c). In part this reflects congestion. Appellate courts in states with 15 or more death verdicts awaiting review evidently get so overburdened that they are unable to finish inspecting the capital verdicts that are currently under review and either reverse or affirm them; at that point, congestion effectively shuts down the review process. Some of this effect remains, however, even after excluding undecided cases, indicating that backlogs also pressure courts to approve verdicts and speed them through the process, perhaps by reviewing them less thoroughly for error.

Fourth, when reversals at all three stages of review are considered, reversal rates increase as the size and density of the states' populations increase. In analyses dominated by state court reversals - when we consider reversals at all three review stages combined, there are about 9 state court reversals for every 1 federal court reversal - death verdicts imposed in states with larger, more concentrated populations are more likely to be overturned by the courts than verdicts imposed in states with smaller populations spread out among smaller communities. Other things equal, the predicted probability of reversal is almost five times higher in the most than in the least densely populated states and years (see Figure 6d). As we discuss below, this effect (alone among the effects we identified) reverses direction when only federal court decisions are considered. State courts are more likely to reverse verdicts imposed in more densely populated areas, while federal courts are less likely to reverse verdicts imposed in those areas. In other words, unlike state courts, federal courts are more likely to reverse verdicts imposed in states where much the population is located in small towns and 
rural areas than verdicts imposed in states with larger, more urban and suburban populations. We address this phenomenon below.

Three additional conditions had smaller but still notable effects - in each case, the predicted probability of reversal at least doubled across the range of values for that condition among the 520 state-years in our study. The probability that a death verdict would be reversed is higher where each of the following predictors are higher: (1) the percentage of the population in the state that is African-American (see Figure 6e); (2) the rate of homicide victimization among the white population divided by the homicide victimization rate among African-Americans; (see Figure 6f); and (3) the electoral pressure on state judges to conform their rulings to popular sentiment (as measured by an index of the frequency and partisan nature of state judicial elections) (see Figure 6g). The interaction of the first two of these factors appears to be positive: error rates are even higher in states with a combination of large African-American populations and high rates of white relative to black homicide victimization than would be predicted by each of those factors by themselves.

\section{Separate state-year analyses of the state direct appeal and federal habeas reviews}

We study the sensitivity of these findings to model specification by varying the analysis in different ways: examining error rates at each stage of review as opposed to combined error rates at all three review stages; examining error rates as the number of reversals per reviewed verdict as opposed to the number of reversals per imposed verdict; and removing time as a random effect and comparing the states' 23-year death-sentencing experiences as a whole. The findings above largely remained under these alternative analyses. There were, however, some interesting differences.

When reversals at only the first (state direct appeal) review stage were analyzed, a new predictor appeared: the predicted probability of reversal triples when per capita direct expenditures on the state court system drop from the highest to the lowest rates among the 450 states and years in the state direct appeal sub-study. Table 3 shows the estimated regression coefficients, and Figure 7 displays the estimated predictive effect of per-capita court expenditures, keeping all other inputs in the model fixed at their average values. We also performed an analysis of the second (post-conviction review) stage, but this yielded no new results beyond those of the combined analysis already presented.

Table 3 about here 


\section{Figure 7 about here}

Things changed more when reversals at only the third (federal habeas) review stage were analyzed, although the change may be in part a function of the lower number of state-years included in this substudy (161). Table 4 displays the results for models including only the statistically significant predictors. State death-sentencing rate, the proportion of the state's population that is African-American, and the rate of homicides among the state's white compared to its African-American populations were not significant predictors of reversals (although the signs for those variables ran in the predicted direction). But a strong new predictor appeared that is highly correlated with the racial-population variable: the predicted probability of reversal quadruples when an index based on the percent of the state's population receiving welfare and its per capita spending on welfare rose from the lowest to the highest values among the 161 state-years in the federal habeas corpus sub-study. Federal courts are more likely to reverse death verdicts from states with high welfare burdens than verdicts from states with lower welfare burdens. (See Figure 8a.) Additionally, the sign of the population size and density factor changed when reversals at only the federal habeas stage are considered. Death verdicts imposed in states with lower populations and population density are more likely to be overturned by federal habeas courts than death verdicts from other states. (See Figure 8b.) Elected state judges seem to be more willing to remove error from death verdicts imposed in urban areas (where the judicial reversals of verdicts may be less visible and less politically controversial) than from death verdicts imposed in small-town and rural communities. Life-tenured federal judges disproportionately bear the burden of reversing flawed verdicts imposed in the latter, non-urban areas.

\section{Table 4 about here}

\section{Figure 8 about here}

\section{Summary of results of state-year analyses}

Overall, high death-sentencing rates are associated with a higher risk of error in the death verdicts that are imposed. Large numbers of death verdicts also keep appellate courts from effectively reviewing capital verdicts for error. Pressures to use the death penalty excessively and unreliably may be generated by a jurisdiction's generally ineffective response to violent crime and by racial factors (fears about crime produced by a state's large African-American population, high rates of homicide that are relatively concentrated among 
white as opposed to black victims, and the interaction of these two factors).

It has long been recognized that changes in the proxies used by politically powerful citizens to measure (sometimes accurately, sometimes not) the level of threat they face from violent crime- for example, rates of violent criminal victimization in the white community and the size of the African-American communityaffect the probability of punitive responses by citizens and officials. As the perceived threat rises, so does the probability that punitive policies will be adopted. ${ }^{5}$ It has also been hypothesized that the political process provides mechanisms, such as frequent, partisan elections of judges, for transmitting political pressures generated by these fears to the public officials who devise and implement penal policies (Brace and Hall, 1993, Bright and Kennan, 1995, Culver, 1999, George and Epstein, 1992, Songer and Haire, 1992, Songer and Tabrizi, 1999, Traut and Emmert 1998).

\section{Case-level analysis of federal habeas review}

Our findings confirm both these insights in regard to one particularly punitive and publicly visible policy: increased use of the death penalty. More importantly, our findings supplement these conclusions with a new one: when highly visible and punitive policies, such as increased use of the death penalty, are adopted in response to political pressures generated by perceived and actual threats to public safety, the policies are prone to be administered in an unreliable manner, characterized by serious error and mistakes. In the case of increased use of the death penalty, such error undermines the quality not only of trial-level judicial decisions about whom to convict of capital murder and whom to sentence to die but also of appellate-level court decisions about which and what proportion of death verdicts to approve for execution. Error breeds more error. Incompetent law enforcement policies aggravate the threat felt by the public, which, in turn, increases the use of the death penalty and the probability of serious error affecting each additional death

\footnotetext{
${ }^{5}$ For a well-known historical account of this process involving the death penalty in eighteenth century England, see Hay (1975). On the impact of the distribution of populations by ethnicity on crime fears and support for punitive policies, see Bobo and Hutchings (1996), Fosses and Kiecolt (1989), Garland (2002), Haney (1997), Jacobs and Carmichael (2002), Mitchell and Sidanius (1995), and Taylor (1998). On the impact of the ethnicity of the victims of homicide, see Baldus et al. (1990), Baldus et al. (1998), Blume et al. (1998), Bowers et al. (2001), Eisenberg et al. (2001), Gross and Mauro (1989), Lynch and Haney (2000), and Paternoster (2003).
} 
verdict that is imposed. And increased numbers of flawed verdicts flooding the capital review process tend to reduce the capacity of that process to catch and correct trial-level error and create pressures to approve death verdicts despite the presence of those flaws.

The analyses we have presented so far are in the aggregate. We also analyzed the ability of factors in individual cases to predict reversal at the third (federal habeas) stage of review. We limited this study to the federal habeas stage of review because of the much larger accumulation of published decisions (and thus available data) at this last review stage compared to the earlier stages. For each of the 600 cases with completed habeas reviews, we collected information on numerous aspects of the crime, defendant, victim, lawyers, timing, judicial proceedings, and errors (alleged and found), using information in published state and federal court decisions in each case.

We fit several logistic regressions to the probability of habeas reversal, considering various individual-level predictors suggested by the literature to be possibly predictive of reversal rates. Table 5 gives summaries of the inputs, and Table 6 displays the estimated logistic regression coefficients and standard errors. The signs of the coefficients make sense, as we briefly discuss.

\section{Table 5 about here}

\section{Table 6 about here}

After controlling for the strength of the factual and legal grounds for reversal in each case, we found that the probability of reversal at the federal habeas stage increased as the case for a death sentence got weaker. Holding other factors constant at their averages, the probability of a reversal increases $18 \%$ with the addition of one mitigating factor, and decreases $18 \%$ with the addition of one aggravating factor. ${ }^{6}$ We also constructed an index of seven additional factors about the defendant or the case that are not consistently treated as formal aggravating factors by capital statutes but that tend nonetheless to increase the seriousness of the offense or the decision maker's perception of its seriousness: whether or not the defendant had a prior

\footnotetext{
${ }^{6}$ U.S. capital statutes list aggravating factors on which jurors are invited to base death sentences and permit jurors to consider mitigating factors cutting the other way. When the sentencing jury, or in some states the sentencing judge, announces a sentencing verdict, the jury or judge is required to list in writing the aggravating and mitigating factors found in the case, which then are reported in published appellate decisions. We used this information in constructing a predictor comprised of the number of formal aggravating circumstances found in the state minus the number of identified mitigating circumstances.
} 
criminal record, abused drugs or alcohol, was drunk at the time of the offense, or committed the killing in his home community, and whether the victim was a woman or had a high status in the community such as a police officer or elected official. These supplemental aggravating factors had the same effect and about the same effect size as the formal aggravating circumstances: The higher the number of additional aggravating circumstances, the lower the probability of reversal, with each additional factor decreasing the probability of reversal by $17 \%$, holding other factors constant.

These results may help explain the relation between high death-sentencing rates and high error rates in our aggregate studies: Error rates increase as jurisdictions expand the category of homicides for which they impose the death penalty to include cases where the factual bases for a death sentence are relatively weaker or more marginal. Conversely, death verdicts imposed in jurisdictions that reserve the death penalty for "the worst of the worst" offenses are less likely to be seriously flawed.

In addition, as we predicted, the better the factual inquiry conducted during prior state court review proceedings, the lower the probability of a federal reversal; capital prisoners who are represented in federal review proceedings by out-of-state lawyers - typically, members of large urban law firms handling the cases pro bono publico or members of public interest law firms specializing in capital litigation, both of which groups tend to be highly prepared and highly or at least adequately compensated-increase the probability of reversal at the federal habeas stage; later death verdicts were less likely to be reversed than earlier ones (this was predicted because the Supreme Court steadily narrowed the capacity of federal judges to reverse capital verdicts during the 23-year study period (Coyne and Entzeroth, 1994, Dow and Dow, 2002, Rivkind and Shatz, 2000); and judges appointed by Republican presidents are less likely to reverse than judges appointed by Democratic presidents. Ethnicity of the defendant and victim had no discernable effect on the probability of federal habeas corpus reversal. When the state of origin of the death verdict and the federal judicial circuit court that reviewed the capital verdict are added as variables, they have no strong or statistically significant predictive value, and the political party of the deciding judges is no longer significant. The non-significance of federal judicial circuit as a predictor of federal habeas outcomes when other important variables are considered is further evidence that ideological differences among the federal circuit courts is not as important an explanation for variance in capital reversals and reversal rates as has been thought. 


\section{County-level analysis}

Rates of imposing and reversing death verdicts can also be examined at the county level. Figure 9 shows the counties with at least one death sentence in the period under study. The map reveals that nearly $60 \%$ of the counties in the 34 death-penalty states that imposed death sentences between 1973 and 1995 imposed no death verdicts during that period. Even in Texas, Louisiana, Missouri and Virginia - states known for their relatively frequent use of the death penalty - a majority of counties did not impose any death verdicts during the 23-year study period. Interestingly, the variance among counties that Figure 9 reveals can be explained based on inter-state variance without positing any additional effect from intra-state variance. We calculated the number of counties with zero death sentences and found that the number was what would be expected from a simple binomial model, allowing states to vary but with identical probabilities of death sentence per homicide for all counties within each state. That is, by this measure, Figure 9 is statistically indistinguishable from a random assignment of counties to categories of those that do and do not use the death penalty, as long as the probability of assignment is allowed to vary between states based on actual state death-sentencing rates and to be proportional to the number of homicides for each county within each state. This provides further support for our hypothesis that states - and not, for example, federal judicial circuits or counties - are the crucial unit of analysis in understanding death penalty patterns.

\section{Figure 9 about here}

Consistent with this hypothesis, our analyses of data at the county level revealed little beyond our statelevel regressions. After controlling for states, there was little evidence of varying rates of reversing death sentences and no evidence of varying death-sentencing rates per homicide among counties. When we fit hierarchical models including county variables, we obtained an estimate of zero for the unexplained variance at the county level. Among these models was one in which we derived predicted values for reversal rates for states and years, then used those predicted values as independent variables in a study of county reversal rates. The predicted values soaked up all of the unexplained variance, and no other predictors (in these particular county models) were significant.

That said, two county-level conditions were significantly related to county capital-error rates, even after controlling for state-level factors, in some of our county analyses. Both effects also appeared in a regression 
study of capital error rates in Florida counties. (Florida is the only state in our study with enough capital verdicts in enough different counties and years to permit a single-state comparison of county capital error rates.) The two significant factors are the number of death sentences imposed in the county per 1000 homicides (the higher a county's death-sentencing rate, the higher the probability that any death verdict it imposes will be reversed because of error) and the county's population size and density (also positively correlated with the probability of error, when errors found at all three review stages are examined). When measured at the state level, both factors were also predictive of state-level reversal rates.

Simple comparisons of similar counties (ones with about the same number of homicides committed there) consistently reveal a tendency among like-sized counties with higher capital-sentencing rates to have substantially higher reversal rates than counties with low death-sentencing rates. Individuals condemned to die by high death-sentencing also tend to be exonerated thereafter (i.e., found to be not guilty, as defined by the Death Penalty Information Center, 2003) at much higher rates than individuals condemned to die by low death-sentencing counties.

\section{$7 \quad$ Policy options}

Various policies have been suggested to reform the current system in which death sentences typically take over ten years to be reviewed, with more than two-thirds ultimately found to be in error. The suggestions fall into three main categories: (1) identifying practices under which death sentences can be made more reliable (Diamond and Levi, 1996, Liebman et al., 2001, Scheck et al., 2000, Symposium, 2002), (2) streamlining the appeals process (Aarons, 1998, Latzer and Cauthen, 2000, Hoffmann, 2000), and (3) reducing the use of the death penalty (Blecker, 2001, Blume and Eisenberg, 1999, Liebman, 2000, 2002). We discuss each in turn.

1. Operating the death penalty more reliably. Our analysis suggests some specific reforms that would be expected to reduce error rates somewhat. Many reversals occur in cases of weak evidence, in which the prosecutors are under political pressure to come up with a death verdict (Gross, 1996, Liebman, 2000). Thus, we suspect that some beneficial effect would be achieved by rules at the trial stage requiring that all police and prosecution evidence bearing on guilt vs. innocence, and aggravation vs. mitigation, be available for presentation at trial. The failure of police and prosecutors to disclose evidence of innocence and mitigation 
before and during trial is a common reason for the overturning of capital verdicts. Another reform that might reduce the rate of reversal is to have better-funded defense lawyers, because more experienced and better prepared defenders can head off the errors at the trial stage that are currently taking up the time of our appellate courts to discover (Berger, 1990-1991, Friedman and Stevenson, 1992, Lefstein, 1996, Moore, 1996, Vick, 1995). Changing the method of selecting judges from election to appointment also might reduce error rates, given the association of higher error rates and the capacity of voters to discipline unpopular judges by voting them out of office (Bright and Keenan, 1995.) The effects of this last reform may be limited, however, given evidence from our study of case-level factors affecting reversals at the federal habeas stage of review that political influences on appointed judges (indicated by the party of the president who appoints federal judges) also may affect reversal rates.

Overall, our study does not lend much hope that error rates may be reduced by a large amount through these reforms if the total death-sentencing rate remains at the current level. The error rate has been high in almost all states (see Figure 4), and our regression analyses found that factors such as political pressure on judges and increased death sentencing rates were predictive of higher error rates. Error rates at the three review stages combined did not markedly decrease over the twenty-three years of administration of the death penalty that we studied, which suggests that experience is not enough to ensure strong verdicts.

2. Streamlining the appeals process. A direct way to reduce the reversal rate would be to change the rules so that appeals could be processed faster and with fewer grounds for reversal. Supreme Court Justice Rehnquist made a proposal of just this sort in a dissenting opinion in 1981 (Coleman v. Balkcom, 1981), and our case-specific analyses provide evidence that the Supreme Court's subsequent narrowing and expediting of federal habeas review - particularly after Rehnquist became the Chief Justice - had the effect of reducing federal habeas reversal rates over time. After our study period, Congress limited federal habeas review even further through the Antiterrorism and Effective Death Penalty Act of 1996, and some states have recently adopted similar limitations on state court review of death verdicts. A slightly less direct, but effective, approach to the same goal is to withdraw public funding for lawyers who represent capital prisoners at the second (state post-conviction) and third (federal habeas corpus) review stages, where no constitutional right to a lawyer applies. The federal statute took this step in 1996, as had Texas in 1995; Florida is considering 
a proposal to do the same starting in 2003. Our case-level study of factors associated with reversals at the federal habeas stage of review shows that the probability that reviewing courts will find serious error affecting capital verdicts and reverse those verdicts decreases when capital prisoners are represented by less skilled and less adequately funded lawyers.

The positive impact of such policies is questionable, however. Our study revealed evidence that lower rates of reversals by federal courts simply displaced more of the burden of reversing seriously flawed verdicts onto state courts, whose reversal rates thereafter rose. The change thus appears to have had little effect on the overall reversal rate and provides no evidence of declining rates of serious error. More generally, there is no reason to expect that making inspections less frequent and thorough would by itself diminish rates of error. Indeed, the opposite effect might be expected, as the declining deterrent influence of reversals leaves trial actors with more latitude to commit errors. Almost inevitably, therefore, the main result of such reforms will be the upholding of death verdicts with serious errors and the execution of persons who were not reliably found to be guilty and to satisfy the conditions required by law for a death sentence to be imposed (Amsterdam, 1999). Recall that, under the current rules, death sentences often cannot be reversed unless there is judged to be a reasonable probability that the outcome of the case could have differed had the error not occurred. And even at the third stage of review, $40 \%$ of cases were found to have reversible errors.

3. Reducing the use of the death penalty. Our habeas study suggests that it is in close cases-those in which a small amount of evidence might tip the outcome in a different direction - the risk of serious error is the greatest. In addition, the overall death-sentencing rate is a strong predictor of reversal rate. These factors suggest that applying the death penalty more sparingly - to the "worst of the worst" offenderswould reduce the rate of error, as well as reducing the total burden on appellate courts and the absolute number of errors.

Reducing the number of death sentences imposed may seem to be politically difficult. As recently as March, 2003, for example, a Gallup poll found that that 47\% of Americans surveyed believe that the death penalty is applied "not often enough" (compared to $22 \%$ who believe it is applied "too often"). Although most Americans doubt that the death penalty deters crime, those who do believe the penalty is a deterrent may fear that imposing it less often would reduce its deterrent effect. 
There is evidence, however, that lower death-sentencing rates are not beyond reach. Support for the death penalty remained high from the early 1980s into the 1990s, with the proportion of respondents giving an affirmative answer to the question, "Are you in favor of the death penalty for a person convicted of murder?", in the $75 \%-85 \%$ range (see Figure 10). Starting in 1995, however, support for the death penalty began dropping, to $71 \%$ in $2001^{7}$. In all these calculations, we exclude those expressing no opinion. Death penalty polls appear to be sensitive to precise wording. The Gallup Poll, which asks "Are you in favor of the death penalty for a person convicted of murder?" consistently registers a few percentage points more support for the death penalty than the ABC/Washington Post Poll, which asks, "Do you favor or oppose the death penalty for persons convicted of murder?" The drop in support for the death penalty has coincided with increasing concern about the risk of mistakes, with most survey respondents believing that between 3 and 10 percent of persons sentenced to death are innocent, and only $53 \%$ believing the death penalty "is applied fairly in this country today" (Gross and Ellsworth, 2002, Jones, 2002). When the question is whether respondents prefer the death penalty to life without possibility of parole (the actual alternative to a death verdict in nearly all death-sentencing states), support for the death penalty drops to $52 \%$, with $43 \%$ favoring life without parole and the rest undecided (Gross and Ellsworth, 2002, Jones, 2002). Depending upon how the question is phrased, anywhere from $42 \%$ to $53 \%$ of the public now support a pause in executions while reforms are considered to make the death penalty more reliable (Gross and Ellsworth, 2002, Jones, 2002).

\section{Figure 10 about here}

Even more important than attitudes are behaviors, which also have changed recently as doubts about the reliability of death verdicts have increased. From 1982 (by which point most states that were going to reinstate the death penalty had done so) to 1999 , the number of death sentences imposed in the U.S. each year remained between 250 and 320. In 1996, 319 capital verdicts were imposed; in 1998 and 1999, the number was 303 and 282, respectively. However, in 2000 (the year Governor Ryan imposed a moratorium

\footnotetext{
${ }^{7}$ The extent of changes in support for the death penalty since the events of September 11, 2001, is unclear. On the Gallup Poll, support for the death penalty rose to $74 \%$ in May, 2002 and remained there as of October. On the similarly worded ABC/Washington Post poll, support for the death penalty has remained in the $69 \%-71 \%$ range in 5 soundings from January, 2000, to January, 2003 (Pollingreport.com, 2002, Sussman, 2003).
} 
on executions after a spate of death row exonerations there (Kirchmeier, 2002, Radelet and Borg, 2000), the number of new death verdicts dropped to 229. In 2001 (the last year in which data are available), the number was 155-the lowest in 22 years (Snell and Maruschak, 2002). The recent trend has been for decreased capital sentencing and declining capital-error rates.

\section{Conclusions}

When a state court gives a death sentence, there is a $68 \%$ chance that it will be overturned by a state or federal court because of serious error. We have also found that where the death penalty is applied more heavily, reversal rates are higher. These findings, along with many specific examples of death sentencing mistakes, have led many leading figures to question the death penalty as it is currently implemented in the United States. For example, Governor George Ryan declared a moratorium on executions in Illinois in 2000, and three years later he granted clemency to all 167 death row inmates in the state based on doubts about the reliability of its death-sentencing procedures. Similarly, Supreme Court Justice Sandra Day O'Connor (a death penalty supporter throughout her career as an Arizona legislator and judge and then a federal supreme court justice) said recently that "if statistics are any indication, the system may well be allowing some innocent defendants to be executed."

Other death penalty supporters find no cause for alarm in high rates of court reversal in capital cases. The death-penalty advocates have two main arguments, which interestingly go in opposite directions. On one hand, they argue that appellate judges are politically biased or are reversing based on technicalities. On the other, they claim that the high reversal rates are evidence that the system works, because the courts are scrutinizing death verdicts carefully and finding errors.

Our data suggest a more realistic view, in which appellate judges are neither anti-death-penalty zealots nor perfect error-detectors. Rather, they are busy people with dockets overflowing with death sentence cases - and, it turns out that most of these cases are seriously flawed. As a byproduct, cases typically take a decade or more to get through the system, and the states that push through higher rates of death verdicts have higher rates of flawed cases.

Death-penalty advocates sometimes dismiss the high reversal rate by claiming that appellate judges are 
politically biased or are reversing based on technicalities. In fact, just under $90 \%$ of the capital reversals were by elected state judges, and of the death penalties overturned by appointed judges, $54 \%$ were appointed by Republican Presidents. Reversals are a national phenomenon, not concentrated in any particular circuit courts or regions of the country. It is hard to believe that all these elected judges, and appointed judges of both parties, are reversing thousands of cases based on technicalities.

Actually, reversals occur when the correct outcome of the trial is in doubt. $80 \%$ of state post-conviction review reversals and over $70 \%$ of federal-court reversals occur because of egregiously incompetent lawyering, prosecutorial misconduct or suppression of evidence, misinstruction of jurors, or judge or juror bias.

It might seem desirable to "streamline" the appeals process, but this would do nothing toward solving the problems listed above, which occur at the original trial.

Supporters of the death penalty also take the opposite tack, arguing that the high reversal rate indicates that the system works and that death sentences are scrutinized carefully. But this claim puts a large burden on appellate judges: now, instead of them being technicality-finding impediments to justice, they must become perfect at detecting lower-court errors. Even if this were so, it cannot be an effective system to propel thousands of cases - most of which are flawed - at appellate courts. What is the purpose of the original trial courts in such a system? For whatever reason, they are pushing through a lot of weak cases and overloading the courts at the next level.

The modern death penalty has been around for 30 years in this country, long enough to have established a pattern of long delays and extremely high error rates. But decades of experience in dozens of states and hundreds of counties also shows that places that use the death penalty less often and reserve it for the worst of the worst cases have lower error rates and put fewer innocent people on death row. Support for the death penalty does not have to mean tolerating error, delay and a large risk of executing the innocent.

\section{References}

Aarons, D. (1998). Getting out of this mess: steps toward addressing and avoiding inordinate delay in capital cases. Journal of Criminal Law and Criminology 89, 1.

Acker, J. R., et al., ed. (1998). America's Experiment with Capital Punishment: Reflections on the Past, Present, and Future of the Ultimate Penal Sanction. Durham, N.C.: Carolina Academic Press. 
Aliotta, J. J. (1988). Combining judges' attributes and case characteristics: an alternative approach to explaining supreme court decisionmaking. Judicature 71, 277.

Amsterdam, A. G. (1999). Selling quick fix for Boot Hill: the myth of justice delayed in death cases. In The Killing State: Capital Punishment in Law, Politics and Culture, ed. A. Sarat, 148. Princeton: Princeton University Press.

Ashenfelter, O., Eisenberg, T., and Schwab, S. (1995). Politics and the judiciary: the influence of judicial background on case outcomes. Journal of Legal Studies $\mathbf{2 4 ,} 257$.

Baicker, K. (2001). The budgetary repercussions of capital conviction. National Bureau of Economic Research Working Paper 8382.

Baldus, D. C., et al. (1990). Equal Justice and the Death Penalty: A Legal and Empirical Analysis.

Baldus, D. C., et al. (1998). Racial discrimination and the death penalty in the post-Furman era: an empirical and legal overview, with recent findings from Philadelphia. Cornell Law Review 83, 1638.

Banner, S. (2002). The Death Penalty: An American History. Cambridge, Mass.: Harvard University Press.

Bedau, H. A. ed. (1997). The Death Penalty in America: Current Controversies. New York: Oxford University Press.

Bedau, H. A., and Radelet, M. L. (1987). Miscarriages of justice in potentially capital cases, Stanford Law Review 40, 21.

Berger, V. (1990-1991). The chiropractor as brain surgeon: defense lawyering in capital cases. New York University Review of Law and Social Change 18, 245.

Bienen, L. (1998). The quality of justice in capital cases: Illinois as a case study. Law and Contemporary Problems 61, 193.

Bilionis, L. D. (2000). The unusualness of capital punishment. Ohio N.U. Law Review 26, 601.

Black, C. L. (1981). Capital Punishment: The Inevitability of Caprice and Mistake, second edition. New York: Norton.

Blecker, R. (2002). Cruelty, retribution, or revenge? The moral case for the death penalty. New York Law School. 
Blume, J., and Eisenberg, T. (1999). Judicial politics, death penalty appeals, and case selection: an empirical study. California Law Review 72, 465.

Blume, J., Eisenberg, T., and Wells, M. (2002). Explaining death row's population and racial composition. Unpublished manuscript.

Blume, J. H., et al. (1998). Post-McCleskey racial discrimination claims in capital cases. Cornell Law Review 83, 1771.

Bobo, L., and Hutchings, V. (1996). Perceptions of racial group competition. American Sociological Review 61, 951.

Bohm, R. M. (1998). American death penalty opinion: past, present, and future. In America's Experiment with Capital Punishment: Reflections on the Past, Present, and Future of the Ultimate Penal Sanction, ed. J. R. Acker et al. 30.

Bowers, W. J. (1984). Legal Homicide: Death as Punishment in America, 1864-1982. Boston: Northeastern University Press.

Bowers, W. J., et al. (2001). Death sentencing in black and white: an empirical analysis of the role of jurors' race and jury racial composition. Univeristy of Pennsylvania Journal of Constitutional Law 3, 171.

Bowers, W. J., and Steiner, B. D. (1999). Death by default: an empirical demonstration of false and forced choices in capital sentencing. Texas Law Review 77, 605.

Brace, P., and Hall, M. G., (1993). Integrated models of judicial dissent. Journal of Politics 55, 914.

Brace, P., and Hall, M. G., (1997). The interplay of preferences, case facts, context, and rules in the politics of judicial choice. Journal of Politics 59, 1206.

Bright, S. B., and Keenan, P. J. (1995). Judges and the politics of death: deciding between the bill of rights and the next election in capital cases. Boston University Law Review 75, 759.

Burnside, F. B. (1999). Comment: dying to get elected: a challenge to the jury override. Wisconsin Law Review 1999, 1017.

Carter, L. E. (1993). Harmless error in the penalty phase of a capital case: a doctrine misunderstood and misapplied. Georgia Law Review 28, 125. 
Clarke, A. W., Lambert, E., and Whitt, L. A. (2000-2001). Executing the innocent: the next step in the Marshall hypotheses. New York University Review of Law and Social Change 26, 309.

Cohen, D. (1996). Law, social policy, and violence: the impact of regional cultures. Journal of Personality and Social Psychology 70, 961.

Cohen, D., and Nisbett, R. E. (1994). Self-protection and the culture of honor: explaining southern violence. Personality and Social Psychology Bulletin 20, 551.

Cole, D. (1999). No Equal Justice: Race and Class in the American Criminal Justice System. New York: New Press.

Coleman, J. E., ed. (1998). Symposium on the ABA's proposed moratorium on the death penalty. Law and Contemporary Problems 61, 1.

Constanzo, M. (1997). Just Revenge: The Costs and Consequences of the Death Penalty. New York: St. Martin's.

Cottrol, R. J. (2000). Death and deterrence: notes on a still inchoate judicial inquiry. In Statistical Science in the Courtroom. ed. J. L. Gastwirth. Heidelberg: Springer-Verlag.

Cowan, C. L., Thompson, W. C., and Ellsworth, P.C. (1984). The effects of death qualification on jurors' predisposition to convict and on the quality of deliberation. Law and Human Behavior 8, 53.

Coyne, R., and Entzeroth, L. (1994). Capital Punishment and the Judicial Process. Durham, N.C.: Carolina Academic Press.

Crocker, P. L. (1997). Concepts of culpability and deathworthiness: differentiating between guilt and punishment in death penalty cases. Fordham Law Revew 21, 66.

Cross, F. B. (1997). Political science and the new legal realism: a case of unfortunate interdisciplinary ignorance. Northwestern University Law Review 92, 251.

Crump, D., and Jacobs, G. (2000). A Capital Case in America: How Today's Justice System Handles Death Penalty Cases from Crime Scene to Ultimate Execution of Sentence. Durham, N.C.: Carolina Academic Press.

Culver, J. (1999). Capital punishment, politics and policies in the states, 1977-1997. Social Changes 32, 
287.

Death Penalty Information Center (2003). Innocence: freed from death row.

http://www.deathpenaltyinfo.org/article.php?scid=6\&did=110.

Diamond, S. S., and Levi, J. W. (1996). Improving decisions on death by revising and testing jury instructions. Judicature 79, 224-232.

Dow, D. R., and Dow, M., ed. (2002). Machinery of Death: The Reality of America's Death Penalty Regime. London: Routledge.

Eisenberg, T., et al. (1996). Jury responsibility in capital sentencing: an empirical study. Buffalo Law Review 44, 339.

Eisenberg, T., et al. (2001). Forecasting life and death: juror race, religion, and attitude toward the death penalty. Judicial Legal Study 30, 277.

Eisenberg., T., and Wells, M. T. (1993). Deadly confusion: juror instructions in capital cases. Cornell Law Review 79, 1 .

Emmert, C. F., and Traut, C. A. (1994). The California Supreme Court and the death penalty. American Political Quarterly 22, 41.

Epstein, L., and Kobylka, J. F. (1992). The Supreme Court and Legal Change: Abortion and the Death Penalty. University of North Carolina Press.

Epstein, L., and Mershon, C. (1996). Measuring political preferences. American Journal of Political Science 40, 261.

Epstein, L., and Rowland, C. K. (1991). Debunking the myth of interest group invincibility in the courts. American Political Science Review 85, 205.

Eskridge, W. N., Ferejohn, J., and Gandhi, N. (2003). Strategic statutory interpretation. Unpublished report.

Faust, R., Rubenstein T. and Yackle, L. W. (1991). The Great Writ in action: empirical light on the federal habeas corpus debate. New York University Review of Law and Social Change 27, 637.

Fitzgerald, R., and Ellsworth, P. (1984). Death qualification and jury attitudes. Law and Human Behavior 


\section{$\mathbf{8}, 31$.}

Flango, V. E., and Ducat, C. R. (1979). What difference does method of judicial selection make? Selection procedures in state courts of last resort. Justice System Journal 5, 25.

Flango, V. E., and Mckenna, P. (1995). Federal habeas review of state court convictions. California Western Law Review 31, 237.

Fosset, M. A., and Kiecolt, K. J. (1989). The relative size of minoirty populations and white racial attitudes. Social Science Quarterly 70, 820-835.

Fox, J. A., Radelet, M., and Bonsteel, J. (1990-1991). Public opinion on the death penalty in the postFurman years. New York University Review of Law and Social Change 18, 499-528.

Friedman, R. E., and Stevenson, B. A. (1992). Solving Alabama's capital defense problems: it's a dollars and sense thing. Alabama Law Review 1, 44.

Garland, D. (2001). The Culture of Control. Chicago: University of Chicago Press.

Garland, D. (2002). The cultural uses of capital punishment. Punishment and Society, to appear.

Garvey, S. P., ed. (2002). Beyond Repair? America's Death Penalty. Durham, N.C.: Duke University Press.

Gelman, A., Carlin, J. B., Stern, H. S., and Rubin, D. B. (1995). Bayesian Data Analysis. London: Chapman and Hall.

George, T. E., and Epstein, L. (1992). On the nature of supreme court decision making. American Political Science Review 86, 323.

Glick, H. R., and Pruet, G. W. (1996). Dissent in state supreme courts: patterns and correlates of conflict. In Judicial Conflict and Consensus: Behavior Studies of American Appellate Courts, ed. S. Goldman and C. Lamb. Lexington: University Press of Kentucky.

Gordon, R. A., Michels, J. L., and Nelson, C. L. (1988). Majority group perceptions of criminal behavior: the accuracy of race-related crime stereotypes. Journal of Applied Social Psychology 26, 148.

Greenberg, J. (1982). Capital punishment as a system. Yale Law Journal 91, 908.

Gross, S. R. (1996). The risks of death: why erroneous convictions are common in capital cases. Buffalo Law Review 44, 469. 
Gross, S. R., and Ellsworth, P. (2002). Second thoughts: Americans' views on the death penalty at the turn of the century. In Beyond Repair? America's Death Penalty, ed. S. P. Garvey. Durham, N.C.: Duke University Press.

Gross, S. R., and Mauro, R. (1989). Death and Discrimination: Racial Disparities in Capital Sentencing. Boston: Northeastern University Press.

Haas, K. C., and Inciardi, J. A., ed. (1988). Challenging Capital Punishment: Legal and Social Science Approaches. Newbury Park, Calif.: Sage.

Hall, M. G. (1992). Electoral politics and strategic voting in state supreme courts. Journal of Politics 54, 427.

Haney, C. (1984). On the selection of capital juries: the biasing effects of the death-qualification process. Law and Human Behavior 8, 121.

Haney, C. (1997). Violence and the capital jury: mechanisms of moral disengagement and the impulse to condemn to death. Stanford Law Review 49, 1447.

Hanssen, F. A. (1999). The effect of judicial institutions on uncertainty and the rate of litigation: the election versus appointment of state judges. Journal of Legal Studies 28, 205.

Harries, K., and Cheatwood, D. (1997). The Geography of Execution: The Capital Punishment Quagmire in America. Lanham, Md.: Rowman and Littlefield.

Hatch, O. (1996). Statement. Congressional Record 142, S3362.

Hay, D. (1975). Authority and the criminal law. In Albion's Fatal Tree: Crime and Society in Eighteenth Century England, ed. D. Hay et al., 17. Middlesex: Penguin Books.

Hoffman, J. L. (1995). Where's the buck? Juror misperception of sentencing responsibility in death penalty cases. Indiana Law Journal 70, 1137.

Hoffmann, J. L. (2000). Substance and procedure in capital cases: why federal habeas courts should review the merits of every death sentence. Texas Law Review $\mathbf{7 8}, 1771$.

Hoffman, J. L. (2001). Violence and the truth. Indiana Law Journal 939, 76.

Hood, R. (1998). Capital punishment. In The Handbook of Crime and Punishment, ed. M. Tonry, 739-776. 


\section{New York: Oxford University Press.}

Huff, C. R. (2002). Wrongful conviction and public policy: the American society of criminology. 2001 Presidential Address. Criminology 40, 1.

Hurwitz, J., and Peffley, M. (1997). Public perceptions of race and crime: the role of stereotypes. Journal of Political Science 41, 375.

Jackson, P. I. (1989). Minority Group Threat, Crime, and Policing. New York: Praeger.

Jacobs, D., and Carmichael, J. T. (2002). The political sociology of the death penalty: a pooled time-series analysis. American Sociological Review 67, 109-131.

Johnson, C. (1987). Law, politics and judicial decision making. Law and Society 21, 325.

Johnson, D. W., Picard, P. R., and Quinn, B. (1997). Churches and Church Membership in the United States: An Enumeration by Region, State and County. Washington: Glenmary Research Center.

Jones, J. M. (2002). In-depth analysis: the death penalty. Gallup Poll News Service, August. www.gallup.com/poll/analysis/ia020830.asp

Kadane, J. P. (1983) Juries hearing death penalty cases: statistical analysis of a legal procedure. Journal of American Sociological Association 78, 544.

Kalven, H., and Zeisel, H. (1966). The American jury and the death penalty. University of Chicago Law Review 33, 769.

Kamin, S. (2000). The death penalty and the California supreme courts: politics, judging and death. Ph.D. dissertation, University of California, Berkeley.

Kennedy, R. (1997). Race, Crime and the Law. New York: Pantheon Books.

Kirchmeier, J. L. (1996). Drink, drugs, and drowsiness: the constitutional right to effective assistance of counsel and the strickland requirement of prejudice. Nebraska Law Review 75, 425.

Kirchmeier, J. L. (2002). Another place beyond here: the death penalty moratorium movement in the United States. University of Colorado Law Review 73, 1.

Kozinski, A., and Gallagher, S. (1995). Death: the ultimate run-on sentence. Case Western Law Review 46, 1. 
Kubik, J. D., and Moran, J. R. (2003). Lethal elections: gubernatorial politics and the timing of executions. Journal of Law and Economics, to appear.

Langbein, L. (1999). Politics, rules and death row: why states eschew or execute executions. Social Science Quarterly 89, 629 .

Latzer, B. (2002). Death Penalty Cases: Leading U.S. Supreme Court Cases on Capital Punishment, second edition. New York: Butterworth Heinemann.

Latzer, B., and Cauthen, J. N. G. (2000). Capital appeals revisited. Judicature 84, 64.

Lefstein, N. (1996). Reform of defense representation in capital cases: the Indiana experience and its implications for the nation. Indiana Law Review 29, 495.

Liebman, J. S. (2000). The overproduction of death. Columbia Law Review 100, 2030.

Liebman, J. S. (2002). Opting for real death penalty reform. Ohio State Law Journal 63, 315.

Liebman, J. S. (2002). Rates of reversible error and the risk of wrongful conviction. Judicature $\mathbf{7 8 .}$

Liebman, J. S., Fagan, J., Gelman, A., West, V., Davies, G., and Kiss, A. (2002). A broken system, part II: why there is so much error in capital cases, and what can be done about it. Columbia University Law School. http://www.law.columbia.edu/media_inquiries/news/2002/broken_system

Liebman, J. S., Fagan, J., and West, V. (2000). A broken system: error rates in capital cases, 1973-1995. Columbia University Law School. http://www.law.columbia.edu/media_inquiries/news/2002/broken_system

Lifton, R. J., and Mitchell, G. (2000). Who Owns Death? Capital Punishment, The American Conscience, and the End of Executions. New York: William Morrow.

Lloyd, R. D. (1995). Separating partisanship from party in judicial research: reapportionment in the U.S. district courts. American Political Science Review 89, 413.

Lofquist, W. S. (2002). Putting them there, keeping them there, and killing them: an analysis of state-level variations in death penalty intensity. Iowa Law Review 87, 1505.

Lynch, M., and Haney, C. (2000). Discrimination and instructional comprehension: guided discretion, racial bias, and the death penalty. Law and Human Behavior 24, 337. 
Markman, S. J., and Cassell, P. G. (1988). Protecting the innocent: a response to the Bedeau-Radelet study. Stanford Law Review 41, 121.

Marquart, J. W., Ekland-Olson, S., and Sorenson, J. R. (1994). The Rope, The Chair, and The Needle: Capital Punishment in Texas, 1923-1990. Austin: University of Texas Press.

McCord, D. (1999). Is death "different" for purposes of harmless error analysis? Should it be? An assessment of United States and Louisiana supreme court case law. Lousiana Law Review 59, 1105.

McCord, D. (2001). An open letter to Governor George Ryan concerning how to fix the death penalty system. Loyola University Chicago Law Journal 32, 451.

Messner, S. F., Anselin, L., Baller, R. D., Hawkins, D. F., Deane, G., and Tolnay, S. E. (1999). The spatial patterning of county homicide rates: an application of exploratory spatial data analysis. Journal of Quantitative Criminology 15, 423.

Mishler, W., and Sheehan, R. S. (1993). The Supreme Court as a countermajoritarian institution? The impact of public opinion on Supreme Court decisions. American Political Science Review 87, 87.

Mitchell, M., and Sidanius, J. (1995). Social hierarchy and the death penalty: a social dominance perspective. Political Psychology 16, 591.

Moore, M. D. (1996). Tinkering with the machinery of death: an examination and analysis of state indigent defense systems and their application to death-eligible defendants. William and Mary Law Review 37, 1617.

Nice, D. (1992). The states and the death penalty. Western Political Quarterly 45, 1037.

Paternoster, R. (1991). Capital Punishment in America. New York: Lexington.

Paternoster, R. (2003). An empirical analysis of Maryland's death sentencing system with respect to the influence of race and legal jurisdiction: final report.

www . urhome.umd.edu/newsdesk/pdf/finalrep.pdf

Pinello, D. R. (1995). The Impact of Judicial Selection Method on State-Supreme Court Policy: Innovation, Reaction, and Atrophy. Westport, Conn.: Greenwood Press.

Pinello, D. R. (1999). Linking party to judicial ideology in American courts: a meta-analysis. Justice System 
Journal 20, 219.

Pollingreport.com (2003). Death penalty. www.pollingreport.com/crime.htm

Pridemore, W. (2000). An empirical examination of commutations and executions in post-Furman capital cases. Journal of Political Economy 102, 799.

Radelet, M. L., Bedau, H. A., and Putnam, C. (1992). In Spite of Innocence-Erroneous Convictions in Capital Cases. Boston: Northeastern University Press.

Radelet, M. L., and Borg, M. J. (2000). The changing nature of death penalty debates. Annual Review of Society 43, 26.

Radelet, M. L., and Mello, M. A. (1992). Death-to-life override: saving the resources of the Florida Supreme Court Florida State University Law Review 20, 195.

Report of the Illinois Governor's Commission on Capital Punishment. (2002). www.idoc.state.il.us/ccp

Revesz, R. L. (1997). Environmental regulation, ideology, and the D.C. Circuit. Virginia Law Review 83, 1717.

Rivkind, N., and Shatz, S. F. (2000). Cases and Materials on the Death Penalty. St. Paul: West.

Sarat, A. (1999). The Killing State: Capital Punishment in Law, Politics and Culture. Princeton: Princeton University Press.

Sarat, A. (2001). When the State Kills: Capital Punishment and the American Condition. Princeton: Princeton University Press.

Scheck, B., Neufeld, P., and Dwyer, J. (2000). Actual Innocence: Five Days to Execution and Other Dispatches From the Wrongly Convicted. New York: Doubleday.

Segal, J. A., Epstein, L., Cameron, C. M., and Spaeth, H. J. (1995). Ideological values and the votes of U.S. Supreme Court justices revisited. Journal of Politics 57, 812.

Segal, J. A., and Spaeth, H. J. (1993). The Supreme Court and the Attitudinal Model. Cambridge University Press.

Shatz, S. F., and Rivkind, N. (1997). The California death penalty scheme: requiem for Furman? New York University Law Review 72, 1283. 
Shiffman, J. (2001). Half of death sentences overturned on appeal. Nashville Tennessean, 23 July, A1.

Sisk, G. C., Heise, M., and Morriss, A. P. (1998). Charting the influences on the judicial mind: an empirical study of judicial reasoning. New York University Law Review 73, 1377.

Slotnick, E. E. (1984). Judicial selection systems and nomination outcomes: does the process make a difference? American Political Quarterly 12, 225.

Snell, T. L., and Maruschak, L. M. (2002). Capital punishment 2001. NCJ Report 197020, Bureau of Justice Statistics, U.S. Department of Justice.

Songer, D., and Haire, S. (1992). Integrating alternative approaches to the study of judicial voting: obscenity cases in the U.S. Courts of Appeals. American Journal of Political Science 36, 963.

Songer, S., and Lindquist, S. A. (1996). Not the whole story: the impact of justices' values on Supreme Court decision making. American Journal of Political Science 40, 1049.

Songer, D., and Tabrizi, S. J. (1999). The religious right in court: the decision making of christian evangelicals in state supreme courts. Journal of Politics 61, 507.

Spurr, S. J. (2002). The future of capital punishment: determinants of the time from death sentence to execution. International Review of Law and Economics 22, 1-23.

Stanley, H. W., and Niemi, R. G. (1999). Vital Statistics on American Politics, second edition. Washington: Congressional Quarterly Press.

Steiker, C. S., and Steiker, J. M. (1995). Sober second thoughts: reflections on two decades of constitutional regulation of capital punishment. Harvard Law Review 109, 355.

Stookey, J. (2003). The Arizona capital punishment system. To appear.

Sunnafrank, M, and Fontes, N. E. (1983). General and crime related stereotypes and incidence of juridic decisions. Cornell Journal of Social Relations 17, 1.

Sussman, D. (2003). Poll: most oppose clearing death row. ABCNews.com, January. abcnews.go.com/sections/us/DailyNews/commutation_poll030124.html

Swanson, R. A., and Melone, A. P. (1995). The partisan factor and judicial behavior in the Illinois Supreme Court. Illinois University Law Journal 19, 303. 
Symposium on addressing capital punishment through statutory reform (2002). Ohio State Law Journal 63, 1.

Symposium on the death penalty: reforming a process fraught with error (2001). Hofstra Law Review 29, 1085.

Tate, C. N., and Handberg, R. (1991). Time binding and theory building in personal attribute models of Supreme Court voting behavior, 1916-88. American Political Review 75, 355.

Tauber, S. C. (1998). On behalf of the condemned? The impact of the NAACP Legal Defense Fund on capital punishment decision making in the U.S. Courts of Appeals. Political Research Quarterly 51, 191.

Taylor, M. C. (1998). How white attitudes vary with the racial composition of local populations. American Sociological Review 63, 512-535.

Traut, C. A., and Emmert, C. F. (1998). Expanding the integrated model of judicial decision making: The California justices and capital punishment. Journal of Politics 60, 1166.

Tyler, T. R., and Weber, R. (1982). Support for the death penalty: instrumental response to crime or symbolic attitude. Law and Sociology Review 17, 21.

Uelmen, G. F. (1989). Review of death penalty judgments by the supreme courts of California: a tale of two courts. Loyala Los Angeles Law Review 23, 237.

Vick, D. W. (1995). Poorhouse justice: underfunded indigent defense services and arbitrary death sentences. Buffalo Law Review 43, 329.

Vidmar, N., and Ellsworth, P. (1974). Public opinion and the death penalty. Stanford Law Review 26, 1245.

Ware, S. J. (2002). Money, politics and judicial decisions: a case study of arbitration law in Alabama. Cap. U. Law Review 30, 583.

Weisberg, R. (1983). Deregulating death. Supreme Court Review 305.

West, V., Fagan, J., and Liebman, J. S. (2001). Look who's extrapolating: a reply to Hoffman. Indiana Law Journal 76, 951.

Williams, M. E., ed. (2002). The Death Penalty: Opposing Viewpoints. New York: Greenhaven.

Wright, H. O., et al. (1995). A comparison of uninformed and informed death penalty opinions: a replication 
and expansion. American Journal of Criminal Justice 20, 58.

Zimring, F. E. (1990-1991). Ambivalence in state capital punishment policy: an empirical sounding. New York University Review of Law and Social Change 18, 729.

Zimring, F. E. (2002) The End of American Capital Punishment. New York: Oxford University Press.

U.S. Supreme Court cases:

Coleman v. Balkcom, 451 U.S. 949 (1981)

Furman v. Georgia, 408 U.S. 238 (1972)

Gomez v. United States District Court, 503 U.S. 653 (1992)

Gregg v. Georgia, 428 U.S. 153 (1976)

Jurek v. Texas, 428 U.S. 262 (1976)

Lockett v. Ohio, 438 U.S. 586 (1978)

Proffitt v. Florida, 428 U.S. 242 (1976)

Harry Roberts v. Louisiana, 431 U.S. 633 (1977) (per curiam)

Stanislaus Roberts v. Louisiana, 428 U.S. 325 (1976)

Woodson v. North Carolina, 428 U.S. 280 (1976) 


\begin{tabular}{|c|c|c|c|c|}
\hline Input variable & mean & sd & $\min$ & $\max$ \\
\hline Death sentences per 1000 homicides & 23 & 24 & 0.1 & 208 \\
\hline Backlog (\# cases) & 5.6 & 7.6 & 0 & 49 \\
\hline Measure of state caseload & 0.2 & 1.0 & -1.0 & 3.0 \\
\hline Percent black & 14 & 10 & 0.2 & 36 \\
\hline wbratio: ratio white/black homicide victimization & 0.2 & 0.1 & 0.001 & 1.1 \\
\hline Index of political pressure on judges & 6.5 & 1.7 & 2 & 9 \\
\hline Alternative index of political pressure & 5.8 & 1.4 & 2 & 8 \\
\hline Imprisonment rate per 100 crimes & 4.7 & 2.1 & 0.9 & 12.9 \\
\hline Index of state population and density & 0.2 & 0.9 & -2.4 & 1.8 \\
\hline Direct expenditures on courts per 100,000 population & 1.7 & 1.2 & 0.02 & 6.0 \\
\hline Party-adjusted judge ideology score & 41 & 13 & 25 & 97 \\
\hline Index of welfare expenditures & -0.4 & 0.7 & -1.6 & 2.6 \\
\hline Year of sentencing & 1985.6 & 5.7 & 1973 & 1995 \\
\hline
\end{tabular}

Table 1: Means, standard deviations, and ranges for each of the inputs in the models for the probability that a death sentence is overturned. All predictors are at the state-year level, and $N=520$, the total number of state-years between 1973 and 1995 with valid death penalty laws. The fitted model is displayed in Table 2 and Figure 6.

\begin{tabular}{lrrr} 
Predictor & model 1 & model 2 & model 3 \\
\hline $\log ($ death sentencing rate) & $0.65(0.09)$ & $0.63(0.09)$ & $0.68(0.96)$ \\
Backlog & $-0.20(0.02)$ & $-0.21(0.02)$ & $-0.20(0.02)$ \\
Caseload & $-0.24(0.12)$ & $-0.30(0.13)$ & $-0.25(0.12)$ \\
Backlog $\times$ caseload & $0.048(0.005)$ & $0.050(0.005)$ & $0.049(0.005)$ \\
$\log (\%$ black) & $0.80(0.18)$ & $0.76(0.18)$ & $0.80(0.18)$ \\
$\log ($ wbratio) & $0.70(0.31)$ & $0.60(0.31)$ & $0.67(0.31)$ \\
$\log (\%$ black) $\times \log$ (wbratio) & $0.15(0.07)$ & $0.13(0.07)$ & $0.14(0.07)$ \\
Index of political pressure on judges & $0.23(0.06)$ & & $0.22(0.06)$ \\
Alternative index of political pressure & & $0.26(0.07)$ & \\
log (imprisonment rate) & $-1.19(0.21)$ & $-1.22(0.21)$ & $-1.18(0.22)$ \\
State population and density & $0.52(0.18)$ & $0.56(0.18)$ & $0.59(0.18)$ \\
Year of sentencing & $-0.06(0.02)$ & $-0.05(0.02)$ & $-0.06(0.02)$ \\
Constant & $1.79(0.76)$ & $1.61(0.77)$ & $1.80(0.76)$
\end{tabular}

Table 2: Estimated coefficients (with standard errors in parentheses) from various overdispersed logistic regression models fit to the probability of reversal (in any of the three stages) by state-year. The models also included random effects for states and years. We focus on model 1 but note that the largest effects persist in the alternative specifications. The estimated average effects of the most important inputs are displayed graphically in Figure 6. The range of each input variable is displayed in Table 1. 


\begin{tabular}{lrr} 
Predictor & model 1 & model 2 \\
\hline $\log ($ death sentencing rate) & $0.44(0.10)$ & $0.35(0.10)$ \\
Backlog & $-0.09(0.01)$ & $-0.08(0.01)$ \\
$\log (\%$ black $)$ & $0.41(0.22)$ & $0.37(0.16)$ \\
$\log$ (wbratio) & $0.73(0.35)$ & $0.21(0.11)$ \\
$\log (\%$ black $) \times \log$ (wbratio) & $0.12(0.07)$ & \\
Index of political pressure & $0.17(0.09)$ & $0.14(0.10)$ \\
$\log$ (imprisonment rate) & $-1.37(0.24)$ & $-1.41(0.24)$ \\
State population and density & $0.47(0.20)$ & \\
log (court expenditures per 100,000) & $-0.39(0.08)$ & $-0.34(0.08)$ \\
Party-adjusted judge ideology score & $0.01(0.01)$ & \\
Year of sentencing & $0.16(0.03)$ & $0.16(0.03)$ \\
Constant & $-0.96(1.00)$ & $-0.37(0.68)$ \\
& &
\end{tabular}

Table 3: Estimated coefficients (with standard errors in parentheses) from overdispersed logistic regression models fit to the probability of reversal in the first (state direct appeal) stage, by state-year. The models also included random effects for states and years. The effects are similar to those obtained by analyzing all three stages together (see Table 2), with the addition of state spending on courts, whose estimated effect is displayed in Figure 7. The range of each input variable is displayed in Table 1.

\begin{tabular}{lrr} 
Predictor & model 1 & model 2 \\
\hline Index of political pressure on judges & $0.36(0.08)$ & \\
Alternative index of political pressure & & $0.49(0.11)$ \\
State population and density & $-0.44(0.17)$ & $-0.58(0.17)$ \\
Welfare expenditures & $0.81(0.17)$ & $1.02(0.19)$ \\
Year of sentencing & $-0.13(0.03)$ & $-0.12(0.03)$ \\
Constant & $-1.30(0.64)$ & $-1.84(0.76)$
\end{tabular}

Table 4: Estimated coefficients (with standard errors in parentheses) from overdispersed logistic regression models fit to the probability of reversal in the third (federal habeas review) stage, by state-year. The models also included random effects for states and years. The smaller sample size of this model results in fewer of the potential predictors being statistically significant compared to the combined and aggregate models summarized in Tables 2 and 3. The predictive effects of welfare expenditures and state population and density (which are different than in the models for the earlier stages) are displayed graphically in Figure 8. The range of each input variable is displayed in Table 1.

\begin{tabular}{lrrrr} 
Input variable & mean & sd & min & $\max$ \\
\hline State evidentiary hearing was held? & 0.25 & 0.43 & 0 & 1 \\
Represented by out-of-state lawyer? & 0.30 & 0.46 & 0 & 1 \\
\# aggravating - \# mitigating circumstances & 1.9 & 1.3 & -5 & 6 \\
Character of offender and victim & 2.0 & 1.2 & 0 & 7 \\
Federal evidentiary hearing was held? & 0.19 & 0.39 & 0 & 1 \\
Year of sentencing & 1980.0 & 3.4 & 1973 & 1995 \\
\# habeas claims presented in the case & 4.5 & 3.6 & 1 & 29 \\
Majority of the reviewing judges appointed by Republicans? & 0.53 & 0.50 & 0 & 1
\end{tabular}

Table 5: Means, standard deviations, and ranges for each of the inputs in the case-level analysis of federal habeas review. All predictors are at the level of the individual case, and $N=598$, the total number of completed habeas reviews. The fitted model is displayed in Table 6. 


\begin{tabular}{lrrrr} 
Predictor & model 1 & model 2 & model 3 & model 4 \\
\hline State evidentiary hearing was held? & $-0.54(0.21)$ & $-0.49(0.22)$ & $-0.43(0.23)$ & $-0.42(0.24)$ \\
Represented by out-of-state lawyer? & $0.49(0.19)$ & $0.44(0.20)$ & $0.49(0.20)$ & $0.61(0.21)$ \\
aggravating - mitigating circumstances & $-0.15(0.07)$ & $-0.17(0.07)$ & $-0.17(0.07)$ & $-0.20(0.07)$ \\
Character of offender and victim & $-0.28(0.07)$ & $-0.22(0.07)$ & $-0.19(0.07)$ & $-0.18(0.09)$ \\
Federal evidentiary hearing was held? & $0.50(0.22)$ & $0.47(0.22)$ & $0.54(0.23)$ & $0.71(0.23)$ \\
Year of sentencing & & $-0.15(0.03)$ & $-0.14(0.03)$ & $-0.12(0.03)$ \\
\# habeas claims presented in the case & & & $-0.15(0.03)$ & $-0.14(0.03)$ \\
Majority appointed by Republicans? & & & & $-0.39(0.20)$ \\
Constant & $0.27(0.21)$ & $304.29(55.87)$ & $280.68(59.39)$ & $246.24(62.63)$
\end{tabular}

Table 6: Estimated coefficients (with standard errors in parentheses) from the logistic regression model fit to the probability of reversal at the third (federal habeas) stage, as a function of case-level factors.
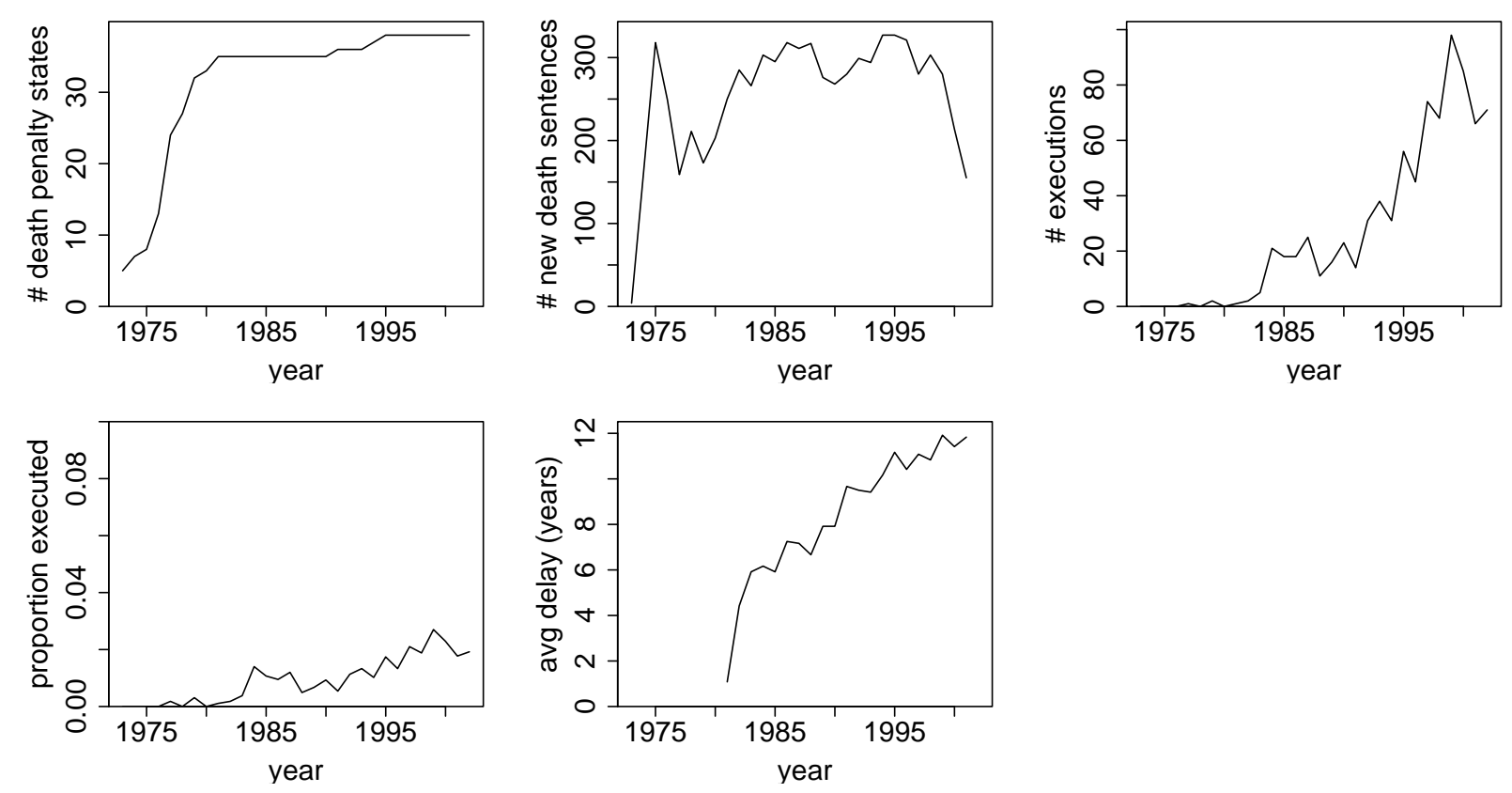

Figure 1: For each year from 1973 through 2002: (a) the number of states with a valid death penalty law, (b) the number of persons sentenced to death that year by U.S. states, (c) the number of persons executed that year, (d) the percent of death row inmates who were executed that year, and (e) the average time since death verdict for that year's executions (skipping the first few years that did not always include executions). 
Figure 2: Outcomes following arrest for homicides committed from 1973 through 1995 in states with the death penalty.

Figure 3: Outcomes of the three stages of the appeals processes and final dispositions of cases (as of 1995) for death verdicts. The uncertainty in the number of cases affirmed in the second review stage and the number under review in the third stage arises because judicial decisions at the second (state post-conviction) stage often are not published. 


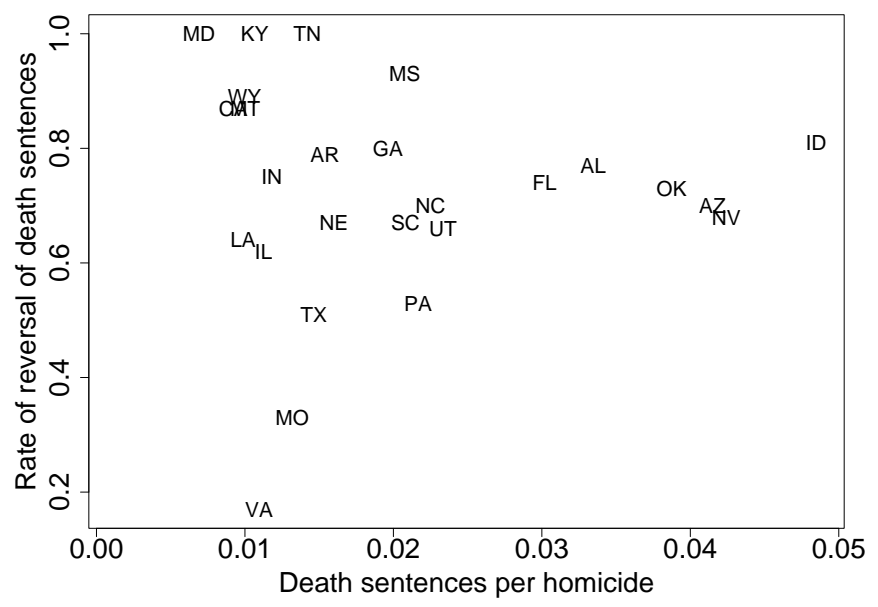

Figure 4: Rates of reversal of death sentences at all three stages of court review vs. the ratio of death sentences per homicide, for each of the 34 states that actively used the death penalty between 1973 and 1995. As of 1995, death verdicts imposed in six states (Connecticut, Oregon, New Jersey, Colorado, New Mexico and Ohio) had only been reviewed at the first, state direct appeal stage, and in two states (Washington and Delaware), the number of death verdicts reversed at the second, post-conviction, review stage is unknown.

Figure 5: For selected federal circuit (regional) courts from 1973 through 1995: the rate at which the circuit court, while conducting federal habeas corpus review, reversed capital verdicts imposed in each of the states within the court's jurisdiction that had the death penalty. 

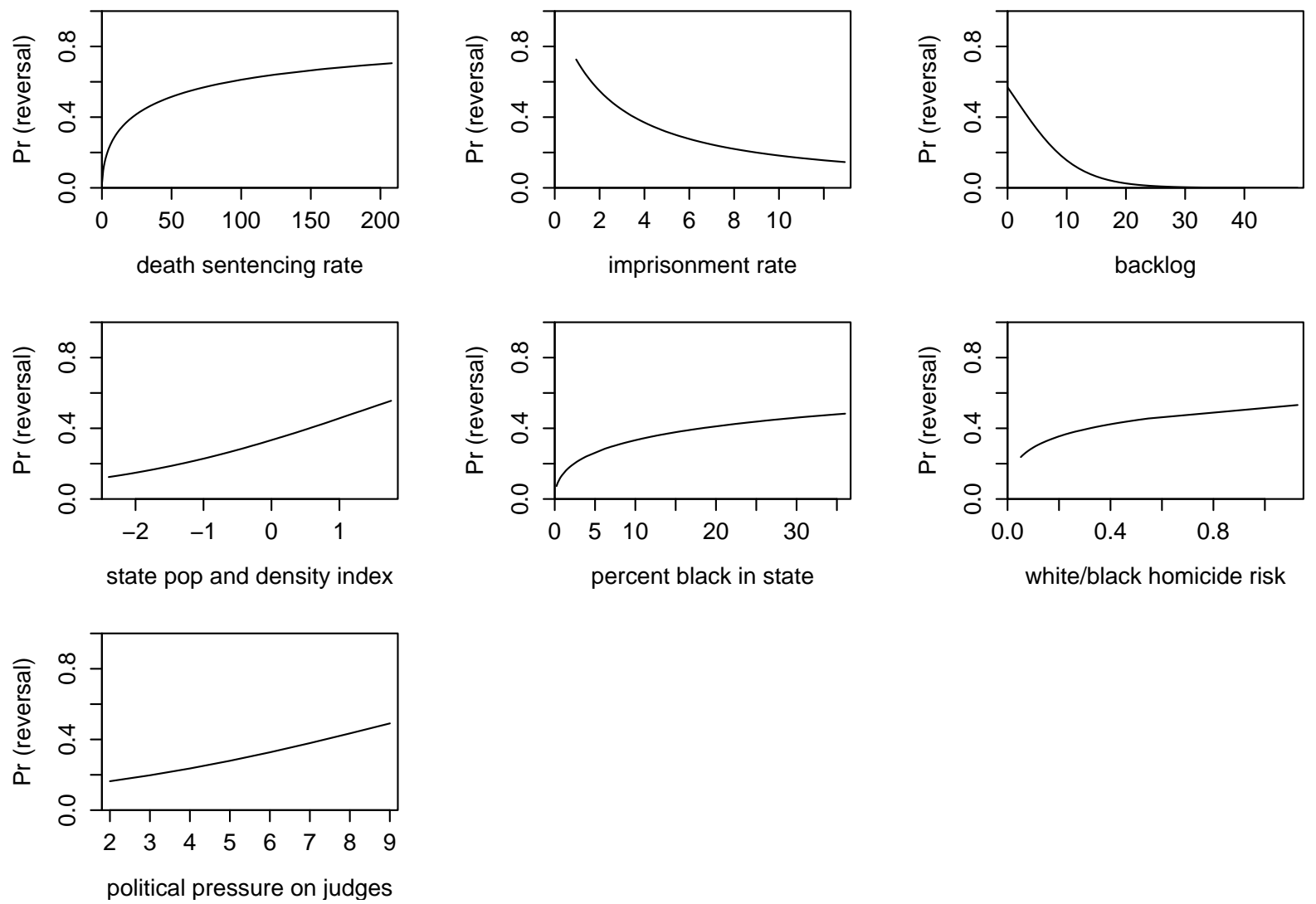

Figure 6: Probability of reversal as a proportion of imposed verdicts at all three stages of court review based on each of several factors, with all other predictors held constant (as estimated from the hierarchical logistic regression model 1 in Table 2). The factors are: (a) state death-sentencing rate, (b) state rate of arrests, conviction, and imprisonment for serious crime, (c) state's backlog of capital verdicts awaiting review, (d) a measure of state population and density, (e) the proportion of African-Americans in the state population, (f) the risk of homicide to state's white residents divided by risk of homicide to state's African-American residents, (g) a measure of the political pressure on state judges. These factors were the most important in a range of regression models we fit, including those displayed in Table 2 and also others fit to each stage of review separately. For each graph, the horizontal axis includes the range of values that occurred in the state-years in our study.

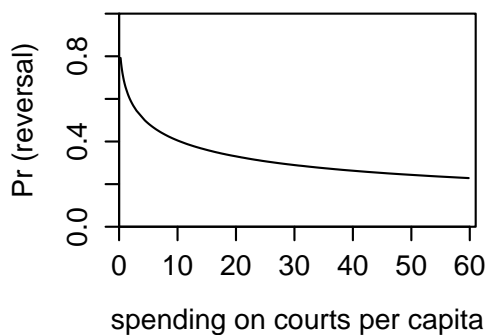

Figure 7: Probability of reversal as a proportion of verdicts actually reviewed at the first (state direct appeal) stage based on state spending on courts (in dollars per million residents), with other factors held constant at their average values, from a logistic regression similar to those shown in Table 2 but fit only to state direct appeal results. The effects of the other important predictors in the model were similar to those shown in Figure 6 . 

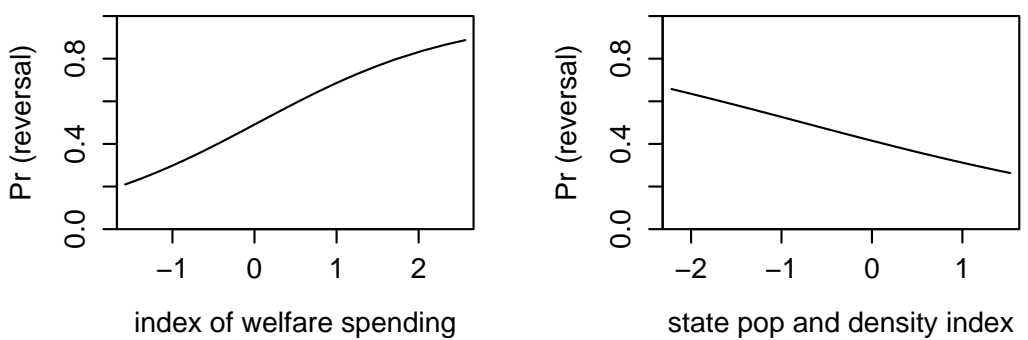

Figure 8: Probability of reversal as a proportion of verdicts actually reviewed at the third (federal habeas corpus) stage based on (a) an index of the percent of state spending on welfare, and (b) the measure of state population and density. The graphs show expected values holding all else constant, from a logistic regression that also controls for an index of political pressure on judges (which has a positive effect as in Figure 6), a time trend, and random effects for states and years.

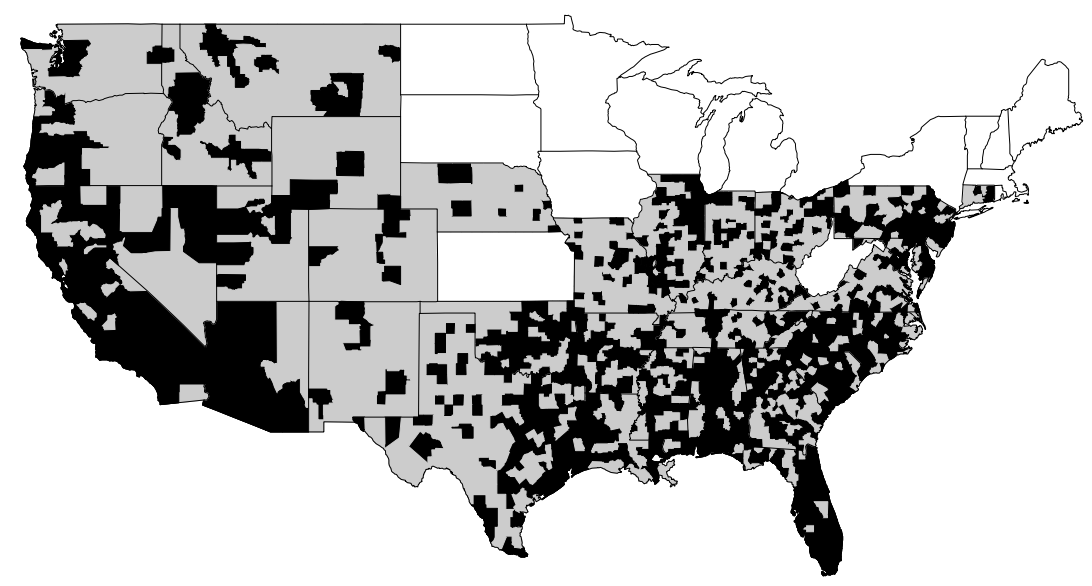

Figure 9: Counties with at least one death sentence in 1973-1995 (dark shading) and counties in deathpenalty states with no death sentences (light shading).

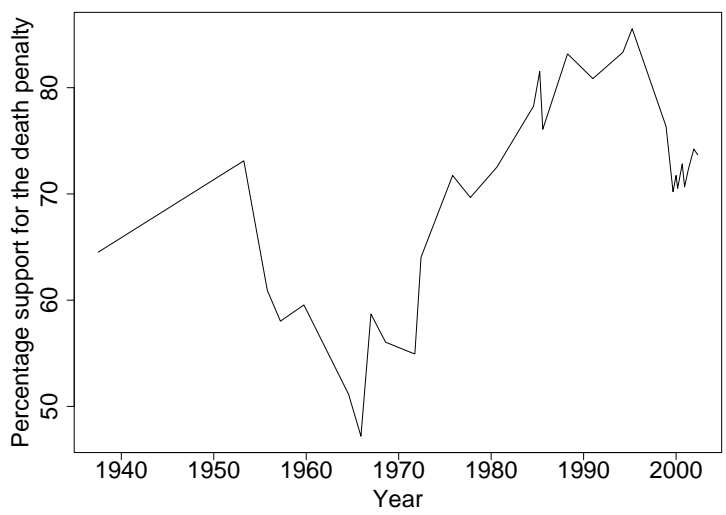

Figure 10: The proportion of adults surveyed who answered yes in the Gallup Poll to the question, "Are you in favor of the death penalty for a person convicted of murder?", among those who expressed an opinion on the question. 


\section{Figure 2}

\begin{tabular}{|c|c|c|c|c|}
\hline Offense/Arrest & $\underline{\text { Prosecution }}$ & Sentencing & $\begin{array}{l}\text { Court Review as } \\
\underline{\text { of } 1995}\end{array}$ & $\begin{array}{l}\text { Most Recent Known } \\
\text { Disposition }\end{array}$ \\
\hline $\begin{array}{l}331,949 \\
\text { homicides } \\
\\
300,257 \\
\text { homicide } \\
\text { arrests } \\
\text { (est.) }\end{array}$ & 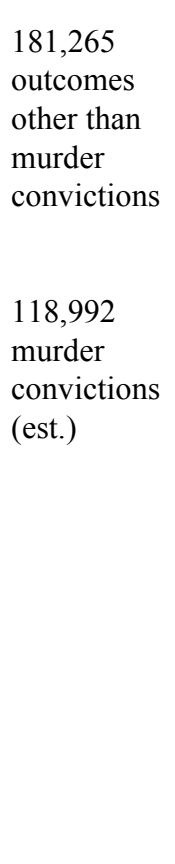 & $\begin{array}{l}113,166 \\
\text { outcomes } \\
\text { other than } \\
\text { death sentences } \\
5826 \\
\text { death } \\
\text { sentences }\end{array}$ & $\begin{array}{l}2349 \\
\text { reversed }\end{array}$ & $\begin{array}{l}66 \text { released; not guilty } \\
\text { (other outcomes unknown) } \\
1 \text { released; not guilty } \\
10 \text { reversed on successive petitions } \\
6 \text { clemency } \\
\text { (55 on death row or unknown) } \\
286 \text { executed } \\
20 \text { released, not guilty, w/o full } \\
\text { court review in study period } \\
-35 \text { clemency prior to full court } \\
\text { review } \\
64 \text { executed w/o full court review } \\
\text { (40 executed from 1973-1995) }\end{array}$ \\
\hline
\end{tabular}


Figure 3

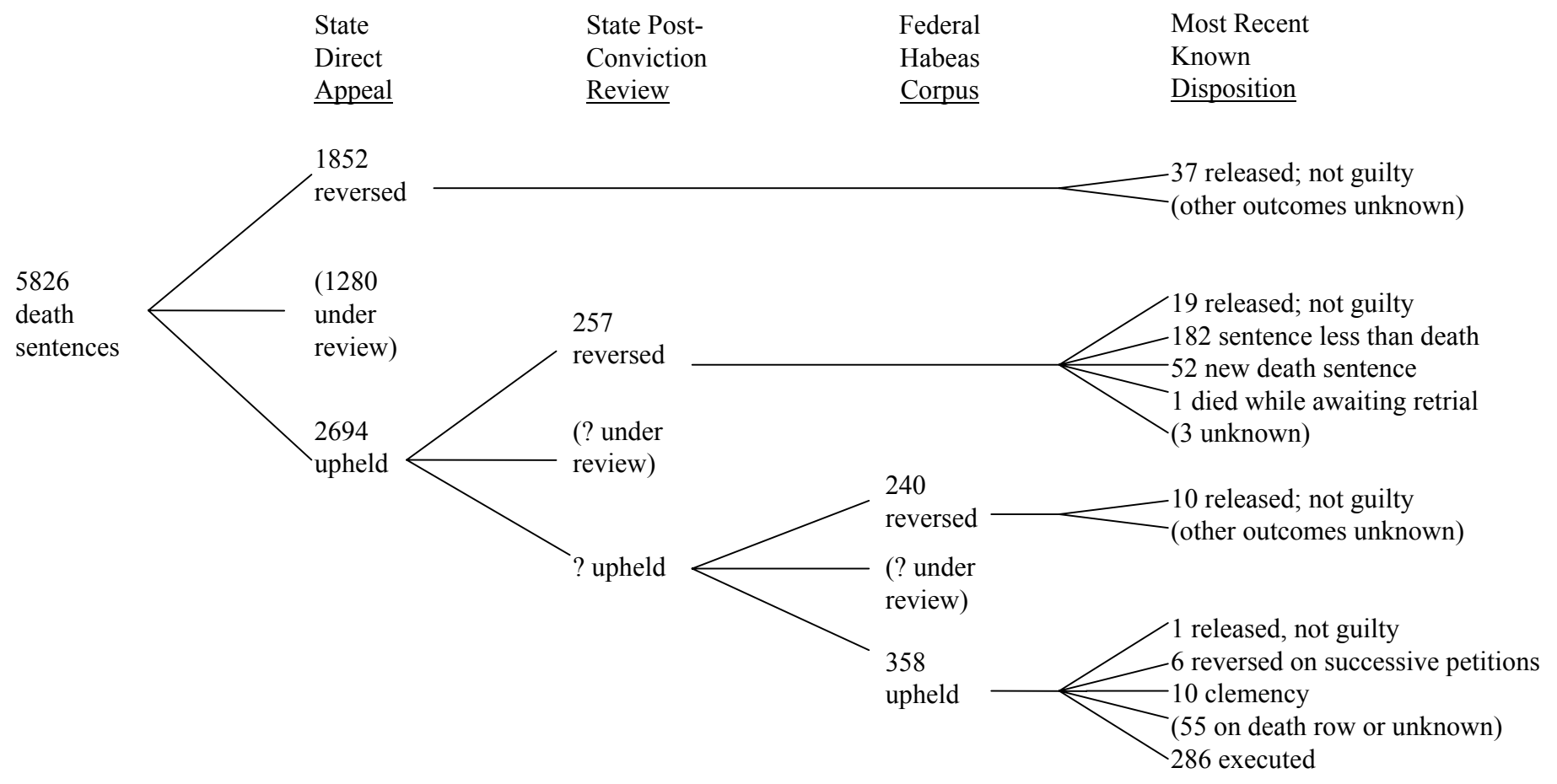


Figure 5

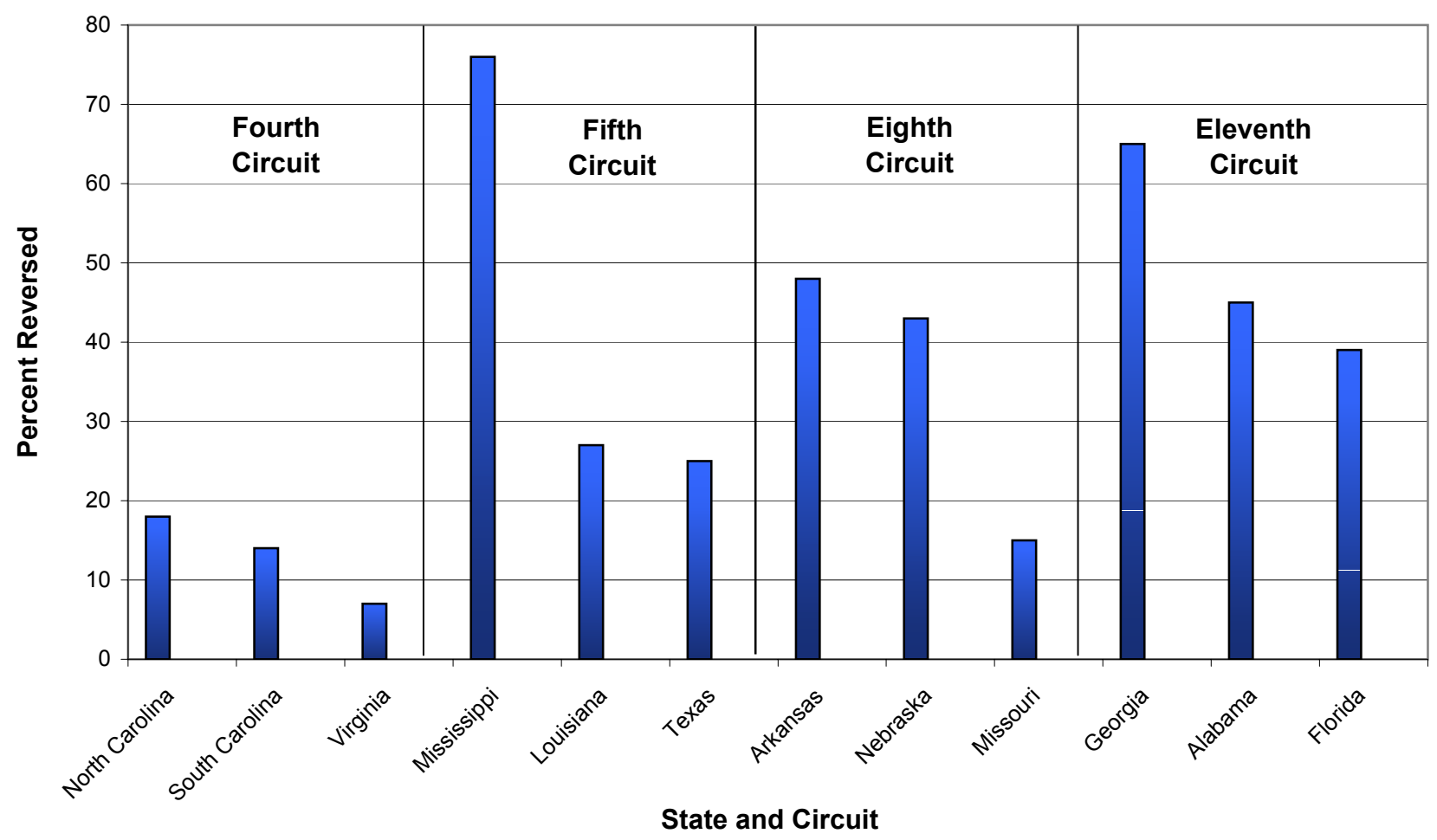

